\title{
Phylogenetic taxonomy and classification of the Crinoidea (Echinodermata)
}

\author{
David F. Wright, ${ }^{1}{ }^{*}$ William I. Ausich, ${ }^{1}$ Selina R. Cole, ${ }^{1}$ Mark E. Peter, ${ }^{1}$ and Elizabeth C. Rhenberg ${ }^{2}$ \\ ${ }^{1}$ School of Earth Sciences, 125 South Oval Mall, Ohio State University, Columbus, OH 43210, USA 〈wright.1433@osu.edu〉, 〈ausich.1@osu.edu〉, \\ $\langle$ cole.678@osu.edu〉,〈peter.1@osu.edu \\ ${ }^{2}$ Department of Geology, Earlham College, 801 National Road West, Richmond, IN 47374, USA 〈rhenbel@earlham.edu〉
}

\begin{abstract}
A major goal of biological classification is to provide a system that conveys phylogenetic relationships while facilitating lucid communication among researchers. Phylogenetic taxonomy is a useful framework for defining clades and delineating their taxonomic content according to well-supported phylogenetic hypotheses. The Crinoidea (Echinodermata) is one of the five major clades of living echinoderms and has a rich fossil record spanning nearly a half billion years. Using principles of phylogenetic taxonomy and recent phylogenetic analyses, we provide the first phylogeny-based definition for the Clade Crinoidea and its constituent subclades. A series of stem- and node-based definitions are provided for all major taxa traditionally recognized within the Crinoidea, including the Camerata, Disparida, Hybocrinida, Cladida, Flexibilia, and Articulata. Following recommendations proposed in recent revisions, we recognize several new clades, including the Eucamerata Cole 2017, Porocrinoidea Wright 2017, and Eucladida Wright 2017. In addition, recent phylogenetic analyses support the resurrection of two names previously abandoned in the crinoid taxonomic literature: the Pentacrinoidea Jaekel, 1918 and Inadunata Wachsmuth and Springer, 1885. Last, a phylogenetic perspective is used to inform a comprehensive revision of the traditional rank-based classification. Although an attempt was made to minimize changes to the rank-based system, numerous changes were necessary in some cases to achieve monophyly. These phylogeny-based classifications provide a useful template for paleontologists, biologists, and non-experts alike to better explore evolutionary patterns and processes with fossil and living crinoids.
\end{abstract}

\section{Introduction}

Crinoids are a diverse, long-lived clade of echinoderms with a fossil record spanning nearly half a billion years and are represented by more than 600 species living in marine ecosystems today (Hess et al., 1999). The geologic history of crinoids is revealed through a highly complete, well-sampled fossil record (Foote and Raup, 1996; Foote and Sepkoski, 1999) displaying a complex pageant of evolutionary radiation, extinction, ecologic innovation, and morphologic diversification (Ausich and Bottjer, 1982; Ausich et al., 1994; Foote, 1999; Peters and Ausich, 2008; Deline and Ausich, 2011; Gorzelak et al., 2015). The spectacular fossil record of crinoids is greatly enriched and complemented by detailed biologic studies on living species. These studies facilitate opportunities to synthesize information from fossil and extant forms. For example, comparative studies between fossil and living crinoid species have provided insight into species ecology and niche dynamics (Meyer and Macurda, 1977; Ausich, 1980; Roux, 1987; Kitazawa et al., 2007; Baumiller, 2008), established developmental bases for morphologic homologies (Shibata et al., 2015a), and informed phylogenetic hypotheses (Simms and Sevastopulo, 1993; Rouse et al., 2013). Thus, crinoids form a data-rich model system for exploring major questions in the history of life.

\footnotetext{
* Present address: Department of Paleobiology, National Museum of Natural History, The Smithsonian Institution, P.O. Box 37012, MRC 121, Washington, DC 20013-7012, USA 〈wrightda@si.edu〉
}

Given their general significance and broad scientific utility across multiple disciplines of inquiry, it is paramount that the biological classification of crinoids reflects their evolutionary heritage. Numerous emendations and informal suggestions for major taxonomic revisions have been opined over the past few decades (e.g., Kelly, 1986; Simms and Sevastopulo, 1993; Ausich, 1998a, 1998b; Webster and Jell, 1999; Hess and Messing, 2011), but the most recent comprehensive revision to crinoid classification is the 1978 Treatise on Invertebrate Paleontology (Moore and Teichert, 1978). Since publication of the Treatise, the value of revising rank-based systematic classifications to be consistent with phylogenetic hypotheses and/or the explicit use of phylogenetic taxonomy (sensu de Quieroz and Gauthier, 1990; Sereno, 1999, 2005) has become increasingly common in paleontology (e.g., Smith, 1984, 1994; Holtz, 1996, 1998; Sereno, 1997; Padian et al., 1999; Brochu and Sumrall, 2001; Carlson, 2001; Carlson and Leighton, 2001; Brochu, 2003; Forey et al., 2004; Sereno et al., 2005; Butler et al., 2008; Kelley et al., 2013). We agree with these authors that all named taxa in a biological classification system should ideally represent clades (i.e., monophyletic groups). The development of phylogeny-based classifications is not without difficulties or criticism (e.g., Benton, 2000, 2007). However, we advocate that recent advances in understanding the phylogenetic relationships of major crinoid lineages make the biological classification of the Crinoidea ripe for revision.

A great strength of so-called 'phylogenetic taxonomy' is its potential for increasing nomenclatural stability (de Quieroz and 
Gauthier, 1994; Brochu and Sumrall, 2001). Under a phylogeny-based system of classification, groups of taxa are organized by their patterns of shared common ancestry rather than diagnostic traits. This is a particularly useful aspect of phylogenetic taxonomy: if named evolutionary units are defined by their history of common ancestry, they do not change if new information comes to light that necessitates modification of taxonomic diagnoses. For example, new fossil discoveries and/ or more nuanced understandings of phylogenetic relationships may alter the distribution of synapomorphies among members of a clade but do not alter the definition of the clade. Moreover, by naming taxa on the basis of cladogram topologies, phylogenetic taxonomy can provide a precise definition for groups previously difficult to diagnose by a unique combination of synapomorphies, such as the Articulata (Simms, 1988; Webster and Jell, 1999; Rouse et al., 2013). To avoid potential instability in taxonomic nomenclature and/or the proliferation of clade names, we advocate that major changes in crinoid systematics should: (1) be based on well-supported phylogenetic hypotheses inferred using rigorous and repeatable quantitative techniques, and (2) employ widely used names and/or names with historical precedence if available.

In this paper, we propose a series of stem-based and nodebased clade definitions to help standardize nomenclature for crinoid higher taxa. The clade definitions proposed herein are informed by a series of recent phylogenetic analyses (Ausich et al., 2015; Cole, 2017; Wright, 2017) and represent the first attempt to classify crinoids using the principles of phylogenetic taxonomy (de Queiroz and Gauthier, 1992, 1994).

Although Linnaean classifications lack rigorous criteria for assigning ranks, they can nevertheless provide useful (if coarse) reflections of phylogenetic relatedness and divergence among taxa, particularly in paleontology (Smith, 1984; Potter and Freudenstein, 2005; Jablonski and Finarelli, 2009; Soul and Friedman, 2015). Given the widespread use of rank-based classifications among invertebrate paleontologists in both alpha taxonomy and paleobiological studies, it is prudent to present a phylogenetically informed revision of the rank-based classification of the Crinoidea. These revisions modify the existing Linnaean classification of crinoids to better represent the set of nested hierarchies implied by phylogenetic trees (Ausich et al., 2015; Cole, 2017; Wright, 2017).

In their review of progress made in crinoid research during the twentieth century, Ausich and Kammer (2001, p. 1167) stated the "immediate challenge for the [twenty-first century] study of crinoids is to establish a phylogenetic classification for the entire class." It is our hope that the dual classification systems presented herein will provide a foundation for future studies employing phylogenetic nomenclature in crinoid research and promote the use of an improved classification system among researchers who choose to work with the Linnaean system.

\section{The dredge and the hammer: a brief history of crinoid classification}

The whole history of the attempts to classify the Crinoidea shows ... the gradual emancipation from the older habit of lumping forms together because they are alike in structure without considering how the likeness arose.

$$
\text { -F.A. Bather (1898, p. 339) }
$$

Formal scientific description and classification of crinoids began in 1821 when J.S. Miller recognized fossilized stalked echinoderms from the "environs of Bristol" as a distinct group. Although he did not include comatulids in his original conception of the Crinoidea, he anticipated that they were crinoids: "The combination of these results with those from the Crinoidea made me anxious to examine the Comatulae ... an animal which would be defined with sufficient precision as a Pentacrinus destitute of the column" (Miller, 1821, p. 127). Further, he judged Marsupites ornatus Miller, 1821 (an unstalked crinoid of Cretaceous age) to be the 'link' between comatulids and his Crinoidea (Miller, 1821, p. 139). Extant stalked crinoids were unknown until the mid- to late 1860 s, when their discovery during oceanic dredging expeditions provided fodder for early debates regarding the efficacy of Darwin's (1859) then recently proposed theory of natural selection (see Alaniz, 2014; Etter and Hess, 2015). Thus, the original description, definition, and diagnosis of the Crinoidea relied entirely on fossil remains. Despite the morphological diversity and deep phylogenetic divergences among groups of extant species, the inclusion of living crinoids with fossil forms has not fundamentally altered Miller's (1821) concept. Following subsequent inclusion of the comatulids and extant stalked crinoids with fossil forms, the Crinoidea has withstood nearly 200 years of scrutiny as a distinct group within the Echinodermata.

In contrast with their long-term recognition as a clade, the classification of taxa within the Crinoidea has been widely debated since the nineteenth century (Müller, 1841; Angelin, 1878; Wachsmuth and Springer, 1897; Bather, 1899; Springer, 1913; Jaekel, 1918). With few exceptions, debates on crinoid classification have primarily been based on disagreements over phylogenetic affinities among taxa rather than systematic practices among researchers (see Bather, 1899 for a counter example). The intensity of early debates over crinoid classification is best epitomized by the frequent yet acrimonious exchanges between Wachsmuth and Springer (e.g., 1885, 1891, 1897) and Bather (e.g., 1898, 1899, 1900). Attempts to resolve these debates among nineteenth-century systematists have largely shaped the last $\sim 70$ years of crinoid research (Ausich and Kammer, 2001).

In their seminal work Evolution and Classification of Paleozoic Crinoids, Moore and Laudon (1943) presented a classification that incorporated aspects of both Frank Springer's and Francis Bather's ideas (see discussion in Ausich and Kammer, 2001). With few modifications, Moore and Laudon's (1943) publication formed the basis of the Treatise on Invertebrate Paleontology (Moore and Teichert, 1978). Following publication of the 1978 Treatise, the classification of crinoids entered a protracted yet frail era of nomenclatural stability. Although few authors have advanced major revisions or comprehensive modifications, many have voiced contention with the Treatise classification (Kelly, 1982, 1986; Kolata, 1982; McIntosh, 1984, 1986, 2001; Ausich, 1986, 1998a, 1998b; Donovan, 1988; Simms, 1988; Simms and Sevastopulo, 1993; Brower, 1995; Webster and Jell, 1999; Guensburg and Sprinkle, 2003; Hess and Messing, 2011; Guensburg, 2012; 
Ausich et al., 2015). With the exception of Simms and Sevastopulo (1993), these studies have been readjustments of the Moore and Teichert (1978) classification to accommodate rank changes, the addition of new groups, and delineation of clade membership defined by phylogenetic studies of extant species.

The study of extant crinoids remains in the shadow of A. H. Clark, who published more than 100 publications on their morphology, taxonomy, and classification during the early to middle twentieth century (e.g., Clark, 1915, 1921; Clark and Clark, 1967). The advent and application of molecular phylogenetic methods to crinoid phylogeny has recently thrown light on relationships among extant species (Cohen et al., 2004; Hemery et al., 2013; Rouse et al., 2013; Summers et al., 2014). However, these analyses also point toward the need for extensive taxonomic revisions and an improved understanding of morphologic traits among living species (Messing and White, 2001; David et al., 2006; Roux et al., 2013; Summers et al., 2014; Hays et al., 2015). Remarkably, there has been little previous work to combine molecular phylogenetic studies of extant crinoids with paleontologic data to assemble a more complete picture of post-Paleozoic crinoid evolutionary history. Efforts to integrate these rich sources of information present both challenges and opportunities for future researchers to resolve patterns and processes shaping the crinoid tree of life (Lee and Palci, 2015; Pyron, 2015).

\section{Crinoid origins and classification}

Extant echinoderms include the Crinoidea, Echinoidea, Ophiuroidea, Asteroidea, and the Holothuroidea, with the latter four comprising the Eleutherozoa. Although it has been long established that crinoids form the sister group to the Eleutherozoa, the relationships among many fossil and extant echinoderm groups are controversial (Paul and Smith, 1984; Sumrall 1997; David et al., 2000; Smith, 2005; Pisani et al., 2012; Telford et al., 2014; Zamora and Rahman, 2014; Feuda and Smith, 2015; Reich et al., 2015). The phylogenetic position of crinoids within the Echinodermata was contested throughout the late twentieth century, with a focal question whether the Pelmatozoa (i.e., stalked echinoderms including blastozoans and crinoids) and/or the Blastozoa are monophyletic groups or a 'grade' of body plan organization. This is a fundamental question not only for understanding the origin of crinoids but also for resolving phylogenetic relationships among clades within the Echinodermata. One hypothesis of crinoid origins postulates that crinoids and blastozoan echinoderms independently evolved pelmatozoan-grade body plans (e.g., Sprinkle, 1973, 1976; Mooi and David, 1998, 2008; David et al., 2000; Guensburg and Sprinkle, 2003; Guensburg, 2012). This hypothesis proposes that blastozoans and crinoids each comprise distinct monophyletic groups. By contrast, an alternative hypothesis postulates that blastozoans and crinoids are members of an inclusive pelmatozoan clade, with crinoids nested within a paraphyletic Blastozoa (Leuckart, 1848; Bather, 1899, 1900; Paul and Smith, 1984; Smith, 1984; Paul, 1988; Smith and Jell, 1990; Smith, 1994; Sumrall, 1997; Ausich, 1998a, 1998b; Clausen et al., 2009; Zamora and Smith, 2011; Kammer et al., 2013; O'Malley et al., 2016). In this hypothesis, the blastozoan body plan represents a grade of organization within the more inclusive Pelmatozoa, a clade comprising all blastozoan-grade echinoderms and crinoids (including the crown group). Although the inclusive group of nominal 'blastozoan' taxa is not monophyletic, there are undoubtedly assemblages of blastozoan taxa that do correspond to monophyletic groups (Smith, 1984; Sumrall and Wray, 2007; Zamora and Smith, 2011; Sumrall and Waters, 2012; Zamora et al., 2016).

Important to this debate are the differences among researchers with respect to their underlying taxonomic principles and systematic practices (see Smith, 1988). Those who support the monophyly of the Blastozoa and Crinoidea embrace systematic practices that emphasize differences (rather than similarities) among taxa, recognize plesiomorphic traits as taxonomically informative characters, exclude character data from consideration of relationships because of a priori beliefs regarding the distribution of homoplastic traits, and conflate sister group hypotheses with ancestor-descendant relationships (e.g., Guensburg and Sprinkle, 2003, 2007; Guensburg, 2012; Guensburg et al., 2016). These practices differ considerably from those that infer the Pelmatozoa as a clade. These workers tend to emphasize similarities (rather than differences) among taxa, minimize a priori assumptions regarding hypotheses of character evolution, and utilize the principles of phylogenetic systematics to rigorously test whether apparent similarities in form reflect synapomorphies or homoplasy (e.g., Sumrall and Waters, 2012; Sumrall, 2014; Ausich et al., 2015). Given the recent advances in homology assessment among pentaradiate echinoderms (e.g., Sumrall, 1997, 2008, 2010, 2014; Sumrall and Waters, 2012; Kammer et al., 2013) and computational phylogenetic analyses of echinoderm taxa based on a large ensemble of characters, it is becoming increasingly clear that a blastozoan-grade taxon likely forms the closest immediate outgroup to the Crinoidea (Kammer et al., 2013; Sumrall, 2014). In the future, new developments in phylogenetic research along with a continued search for the oldest 'crinoid' fossils will continue to play a role in uncovering the sequence of morphologic transitions behind the assembly of the crinoid body plan.

Despite desultory disagreements regarding crinoid origins (Sprinkle, 1973; Ubaghs, 1978; Donovan, 1988; Ausich, 1998a, 1998b; Ausich and Babcock, 1998; Guensburg and Sprinkle, 2007, 2009; Guensburg, 2012; Kammer et al., 2013; Ausich et al., 2015; Guensburg et al., 2016), there is nevertheless considerable agreement among workers regarding the pattern of branching relationships within the crinoid ingroup. For example, the recent phylogenetic analyses of Guensburg (2012) and Ausich et al. (2015) reveal highly congruent patterns of branching relationships among crinoid higher taxa despite the use of alternative outgroups, different data sets, and alternative interpretations of homologous morphologic characters. We surmise this growing consensus stems from the improved taxonomic sampling of the oldest known crinoids (Guensburg and Sprinkle, 2003, 2009; Guensburg, 2010) and implementation of more rigorous quantitative approaches to testing phylogenetic hypotheses (Guensburg, 2012; Ausich et al., 2015; Cole, 2017; Wright, 2017).

We conclude that congruence observed among tree topologies obtained from researchers with different perspectives indicates strong support for these patterns. Although questions 
surrounding crinoid origins remain, this debate is moot with respect to the phylogeny-based definitions and classification presented herein and ultimately has no bearing on the focus and conclusions of this paper.

\section{Toward a phylogenetic classification of the Crinoidea}

From the perspective of their geologic history, crinoids are a bottom-heavy clade (Gould et al., 1987). In contrast to the tremendously diverse assemblage of stem lineages, comparatively few species are encompassed within the crown group (Fig. 1). Because of the enormous diversity of the stem group relative to the crown group, fossil crinoids have received much systematic attention compared to their extant representatives (but see Clark, 1915; David et al., 2006; Hess and Messing, 2011; Hemery et al., 2013; Rouse et al., 2013). Aside from a number of smaller studies examining relationships among species of middle to late Paleozoic genera (e.g., Gahn and Kammer, 2002; Kammer and Gahn, 2003; Ausich and Kammer, 2008), most investigations of crinoid phylogeny have focused on discerning relationships among Ordovician taxa (Brower, 1995; Ausich 1998b; Guensburg, 2012; Ausich et al., 2015; Cole, 2017). The Ordovician Period represents a key interval in crinoid evolution because species belonging to various groups of traditionally named taxa first appear in rocks of the Lower Ordovician (Tremadocian) (Guensburg and Sprinkle, 2003, 2009; Guensburg, 2010) and the majority of well-studied groups had originated prior to its close.

The divergence between camerate and non-camerate lineages forms a fundamental, early split in the history of crinoid evolution (Jaekel, 1918; Donovan, 1988; Guensburg, 2012; Ausich et al., 2015; Cole, 2017; Wright, 2017) (Fig. 1). For example, in the recent phylogeny of Ausich et al. (2015), taxa belonging to the Camerata (sensu Moore and Teichert, 1978) form the sister clade to all other crinoids, including the protocrinoids (Guensburg and Sprinkle, 2003). Disparids were recovered as sister to a clade comprised of most 'cladid' taxa, and hybocrinids were recovered as sister to a group of 'cyathocrine' cladids (sensu Moore and Teichert, 1978). A similar pattern was recovered by Guensburg (2012, fig. 2).

Building on these studies, Cole (2017) further assessed the basal split between camerates and non-camerates and tested the taxonomic status of the Monobathrida and Diplobathrida (Fig. 1). Wright's (2017) analysis of relationships among noncamerate crinoids offers a more nuanced perspective of this portion of the crinoid tree than previously recovered. Notably, many so-called Ordovician clades of Guensburg (2012) and Ausich et al. (2015) do not retain their status of monophyly when post-Ordovician taxa are considered (Wright, 2017).

Recent molecular phylogenetic studies indicate broad relationships among major clades of extant crinoids are also reaching a consensus, with the Isocrinida representing the sister clade to all other extant crinoids (Rouse et al., 2013, 2015). It is interesting to note that divergence time estimation based on relaxed molecular clock models suggests the split between isocrinids and other extant groups took place some 231-252 million years ago (Rouse et al., 2013). Thus, molecular phylogenetic analyses and paleontological evidence are in general agreement regarding an ancient origin of the crinoid crown group.

A summary tree based on results presented by Rouse et al. (2013), Ausich et al. (2015), Wright (2017), and Cole (2017) is depicted in the form of a simplified cladogram in Figure 2. This cladogram is annotated with the clade names we propose below. Terminal taxa in the cladogram were carefully chosen to maximize stability in phylogenetic nomenclature (Table 1). Sereno (2005) listed numerous criteria for choosing taxon specifiers in clade definitions. These recommendations include choosing specifiers that are nested rather than basal (if possible), represented by well-known or readily available material, and using multiple specifiers where necessary to accommodate phylogenetic uncertainty and/or alternative hypotheses. We have carefully chosen our clade definitions to not hinge on labile phylogenetic hypotheses or specific interpretations of unusual and/or problematic taxa.

Classes of clade definitions used in phylogenetic taxonomy and their graphical representations used herein closely follow Sereno (1999, 2005). Node-based clade definitions circumscribe the most recent common ancestor of at least two taxa and all of its descendants. Thus, node-based definitions form the least inclusive clade containing a minimum of two specifiers. By contrast, stem-based definitions circumscribe the most inclusive clade containing at least one internal specifier. In both cases, additional precision is obtained by identifying external specifiers falling outside the clade (i.e., the outgroup). For example, a stembased definition for hypothetical Clade $A$ with two internal and one external taxon specifiers can be stated as 'all species sharing a more recent common ancestor with species $X$ and $Y$ than $Z$,' where $X$ and $Y$ are internal taxon specifiers and $Z$ is an external specifier. In other words, Clade $A$ is stem-defined as the most inclusive clade containing $X$ and $Y$ but not $Z$. Note the presence of one species as an external specifier effectively eliminates the entire clade to which it belongs. By definition, a clade cannot contain an ancestor of its sister group.

In phylogenetic taxonomy, clade membership is not determined by the presence or absence of a 'key' morphologic feature unless that apomorphy (or set of apomorphies) is listed in the definition as a qualifying clause (Sereno, 2005). We avoid apomorphic qualifiers in our definitions for several reasons. First, incomplete preservation may lead to cases where it is unknown whether a fossil species has the key feature diagnostic of the clade in question. Thus, the inclusion or exclusion of a fossil species depends on character state optimizations rather than direct data. Second, a trait may be 'absent' in a taxon either because it was truly absent or because it was secondarily lost. Similarly, a trait may be 'present' because of convergent

Figure 1. Taxa representing major crinoid clades: (1) Pentacrinites fossilis Blumenbach, 1804, articulate, from Goldfuss (1831); (2) Taxocrinus colletti White, 1881, flexible, from Springer (1920); (3) Actinocrinites jugosus (Hall, 1859), monobathrid camerate, from Wachsmuth and Springer (1897); (4) Synbathocrinus swallovi Hall, 1858, disparid, from Wachsmuth and Springer (1897); (5) Dendrocrinus caduceus Hall, 1866, eucladid, from Meek (1873); (6) Hybocystites eldonensis Parks, 1908, hybocrinid, from Springer (1911); (7) Porocrinus shawi Schuchert, 1900, porocrinid, from Kesling and Paul (1968); (8) Archaeocrinus microbasalis (Billings, 1857), diplobathrid camerate, from Wachsmuth and Springer (1897). Scale bars $=0.5 \mathrm{~cm}$ and applicable as indicated. 


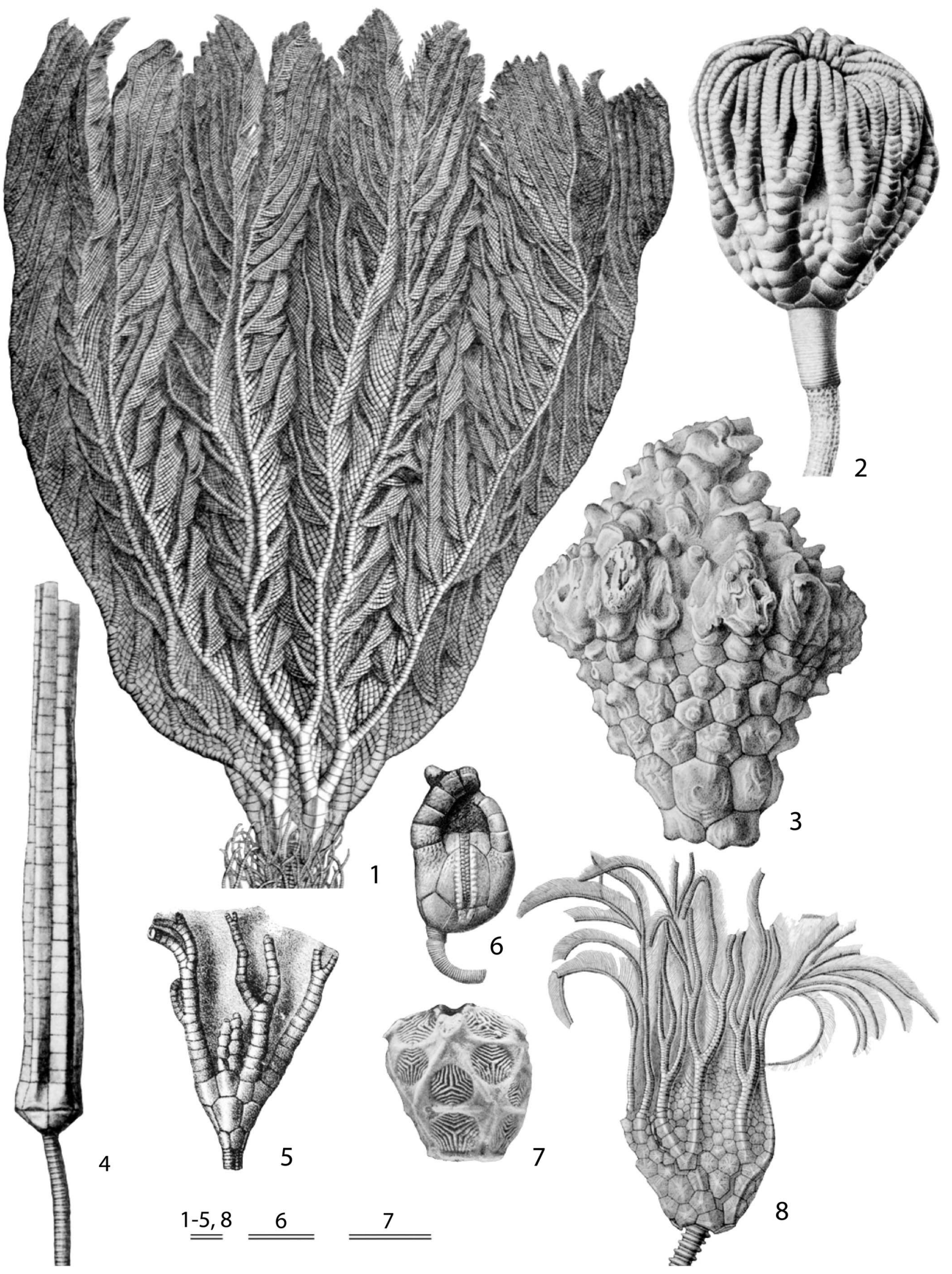


evolution. Moreover, stem group taxa commonly have highly heterogeneous distributions of apomorphic traits, which may lead to instability when new taxa are sampled and/or alternative topologies are equally likely. Finally, the timing of a divergence event may not correspond with the acquisition of a diagnostic apomorphy. For example, the blastozoan Macrocystella is widely recognized as a basal glyptocystitoid rhombiferan even though it lacks the respiratory structures traditionally 'diagnostic' of the Glyptocystida (Paul, 1968; Sprinkle, 1973; Zamora et al., 2016). All of these considerations are highly important when considering patterns of character evolution but may lead to nomenclatural instability if incorporated into clade definitions.

Although we avoid the use of apomorphies to define clades, we do discuss morphological traits potentially useful for taxonomic diagnoses. In some cases, our proposed clade definitions retain much of their traditional meaning and taxonomic content, with constituent taxa sharing numerous synapomorphies that form unambiguous taxonomic boundaries (e.g., the Flexibilia). However, in other cases, either substantial revision was necessary and/or a list of unambiguous diagnostic characters was difficult or impossible to obtain (e.g., the Articulata). These challenges highlight the utility of phylogenetic taxonomy. For example, many authors have remarked that the Articulata has lacked a concise, unambiguous definition since it was first erected by Miller nearly 200 years ago (Simms, 1988; Webster and Jell, 1999; Hess and Messing, 2011; Rouse et al., 2013). A phylogenetic definition of the Articulata provides a clearer criterion for clade membership and results in a framework for future phylogenetic research assessing relationships among hypothesized stem clades, crown group synapomorphies, and subsequent morphologic transitions among crown group subclades.

The clade definitions and revised classification proposed herein represent the present state of knowledge, but systematics is a dynamic science and taxonomic theories are commonly reinterpreted in light of new discoveries. We fully expect our definitions to be refined and/or modified as more information becomes available. Some places of the crinoid tree still require extensive taxonomic revisions, such as upper Paleozoic 'cladids' (sensu Moore and Laudon, 1943) and stem articulates (Wright, 2015b). Despite these potential vicissitudes in the taxonomic content and/or definitions within our proposed classification, we agree with G.G. Simpson's sentiment: "It is pusillanimous to avoid making our best efforts today because they may appear inadequate tomorrow" (1944, p. xxx [sic]).

\section{Systematic paleontology}

\section{Crinoidea Miller, 1821}

Definition.-The Crinoidea is stem-defined as the most inclusive clade containing Rhodocrinites verus Miller, 1821, Actinocrinites triacontadactylus Miller, 1821, and Pentacrinites fossilis Blumenbach, 1804 but not Rhopalocystis detombesi Ubaghs, 1963, Echinosphaerites aurantium (Gyllenhaal, 1772), Eumorphocystis multiporate Branson and Peck, 1940, Protocrinites ouiformis Eichwald, 1840, Cheirocystis antiqua Paul, 1972, Glyptocystella loeblichi (Bassler, 1943), Cambraster cannati Miquel, 1894, and Cambroblastus enubilatus Smith and Jell, 1990.
Remarks.-This definition captures J. S. Miller's (1821) original concept based on fossil specimens and retains the name 'Crinoidea' as the clade comprising the crown group plus all extinct species sharing a more recent common ancestor with a living crinoid than any echinoderm taxon listed in the preceding as external specifiers (Fig. 2). Further, this definition closely resembles the traditional use and taxonomic content of the Crinoidea as used by both biologists and paleontologists (Bather, 1899; Clark, 1915; Jaekel, 1918; Moore and Teichert, 1978; Hess et al., 1999; Rouse et al., 2013) and accommodates the current state of uncertainty regarding their nearest extinct sister group. In the interest of preserving the taxonomic content and common meaning of a widely used name, our Clade Crinoidea is preferred over Sumrall's (1997) similarly defined Crinoidoformes (see Cantino and de Queiroz, 2010, p. 42). The Crinoidea is comprised of two major clades, the Camerata and the Pentacrinoidea, reflecting the early divergence between camerate and non-camerate crinoids (Jaekel, 1918; Donovan, 1988; Guensburg, 2012; Ausich et al., 2015). Because we provide the Crinoidea with a stem-based definition, the discovery of stemward fossils is accommodated within this definition.

Internal taxon specifiers were chosen because they were included in Miller's (1821) original description and represent well-known, well-preserved, and highly nested members of their respective subclades. In contrast to the internal taxon specifiers, the choice of external specifiers is more complex. The use of external specifiers in this definition spanning various 'blastozoan' and edrioasteroid-grade groups reflects the current difficulty involved in postulating the nearest definitive sister group as well as the uncertain state of relationships among extinct stemmed echinoderms (Smith, 1984; Sumrall, 1997, 2014; Ausich, 1998a, 1998b; Guensburg and Sprinkle, 2009; Kammer et al., 2013; Ausich et al., 2015; Guensburg et al., 2016; O’Malley et al., 2016).

The analysis of Ordovician crinoids by Ausich et al. (2015) took a conservative approach to outgroup selection by sampling broadly across taxa nested within the Clade Pelmatozoa (Kammer et al., 2013; Sumrall, 2014). Similarly, we have chosen species from multiple pelmatozoan groups as external specifiers to help provide nomenclatural stability in the presence of phylogenetic uncertainty. Other taxa hypothesized to represent the crinoid sister group include the stylophorans (David et al., 2000) and edrioasteroids (Guensburg and Sprinkle, 2009; Guensburg et al., 2016). Stylophorans have long been considered non-radiate stem group echinoderms (e.g., Paul and Smith, 1984; Smith, 1984, 2008) and have been cogently demonstrated to lack crown group synapomorphies (Smith, 2005). Thus, we do not consider the stylophoran hypothesis further. Guensburg and Sprinkle (2009) and Guensburg et al. (2016) regard edrioasteroid echinoderms, such as the stromatocystidid Cambraster or the edrioblastoid Cambroblastus, to possess apomorphies indicating they share a more recent common ancestor with crinoids than with other echinoderms. Although this hypothesis contrasts with previous studies regarding edrioasteroids as stem group eleutherozoans (Paul and Smith, 1984; Smith 1984, 1985, 1990; Smith and Zamora, 2013), recent investigations suggest that edrioasteroids may comprise a para- or polyphyletic group (Kammer et al., 2013; Zamora, 2013; Zamora and Rahman, 2014). Some 


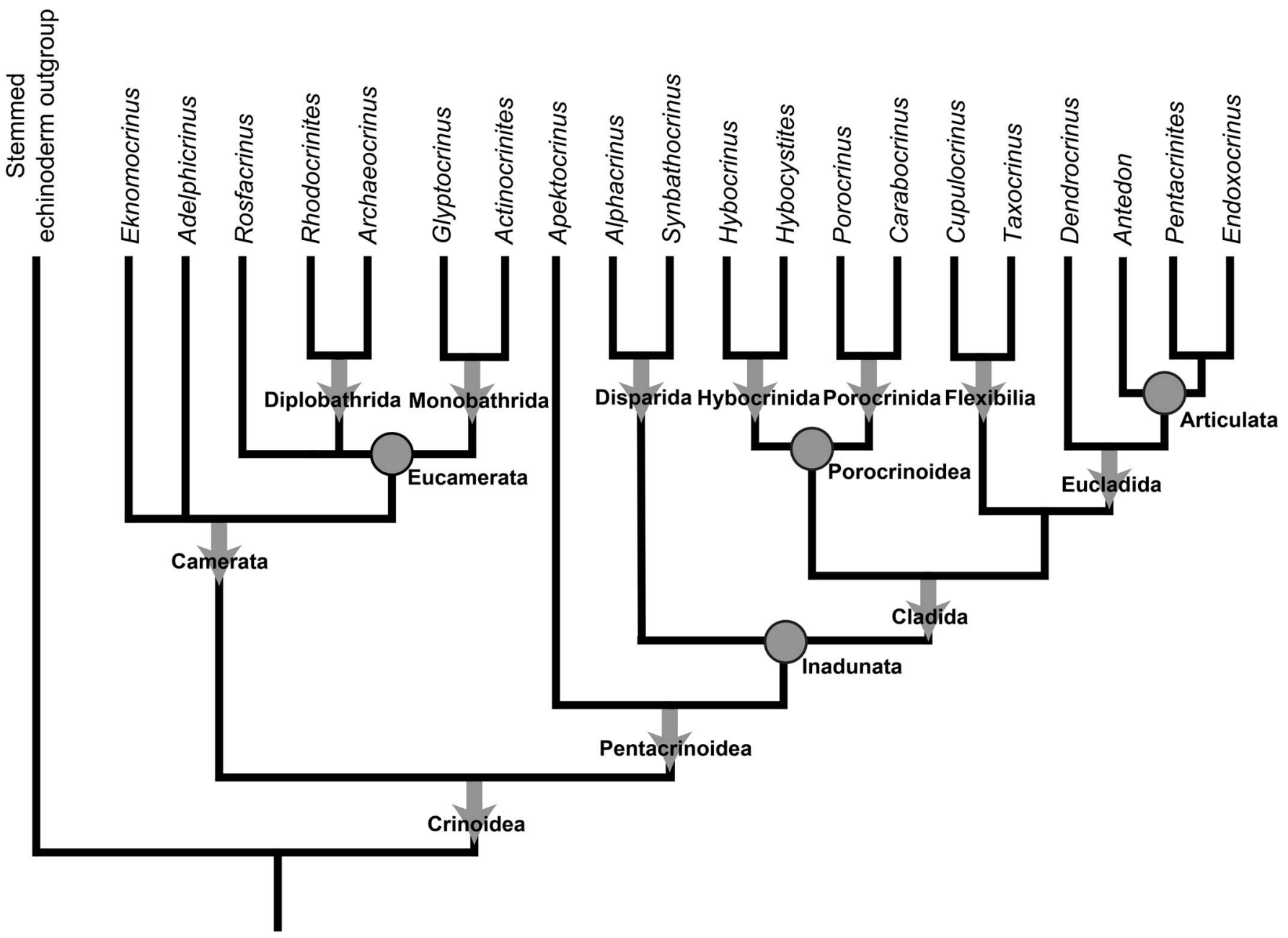

Figure 2. Cladogram depicting phylogenetic relationships among species used to define major clades within the Crinoidea. Terminal tips correspond to species listed in Table 1. Clades given stem-based definitions are indicated with a downward-facing arrow; clades given node-based definitions are indicated with a circle. Note that many clades named are nested inside other more inclusive clades. Graphical notation of stem- and node-defined clades follows Sereno (2005).

Table 1. Species name, least inclusive clade, and first appearance interval for each taxon depicted in Figure 2.

\begin{tabular}{|c|c|c|}
\hline Species & Least Inclusive Clade & First Occurrence of Species \\
\hline Actinocrinites triacontadactylus Miller, 1821 & Monobathrida & $\begin{array}{l}\text { Mississippian (Tournaisian) } \\
\text { (T) }\end{array}$ \\
\hline Adelphicrinus fortuitus Guensburg and Sprinkle, 2003 & Camerata & Ordovician (Tremadocian) \\
\hline Alphacrinus mansfieldi Guensburg, 2010 & Disparida & Ordovician (Tremadocian) \\
\hline Antedon bifida (Pennant, 1777) & Articulata & Recent \\
\hline Apektocrinus ubaghsi Guensburg and Sprinkle, 2009 & Pentacrinoidea & Ordovician (Tremadocian) \\
\hline Archaeocrinus lacunosus (Billings, 1857) & Diplobathrida & Ordovician (Katian) \\
\hline Carabocrinus radiatus Billings, 1857 & Porocrinida & Ordovician (Sanbian) \\
\hline Cupulocrinus heterocostalis (Hall, 1847) & Flexibilia & Ordovician (Katian) \\
\hline Dendrocrinus longidactylus Hall, 1852 & Eucladida & Silurian (Wenlockian) \\
\hline Endoxocrinus parrae (Gervais, 1835) & Articulata & Recent \\
\hline Eknomocrinus wahwahensis Guensburg and Sprinkle, 2003 & Camerata & Ordovician (Tremadocian) \\
\hline Glyptocrinus decadactylus Hall, 1847 & Monobathrida & Ordovician (Katian) \\
\hline Hybocrinus conicus Billings, 1857 & Hybocrinida & Ordovician (Sanbian) \\
\hline Hybocystites problematicus Wetherby, 1880 & Hybocrinida & Ordovician (Katian) \\
\hline Pentacrinites fossilis Blumenbach, 1804 & Articulata & Triassic (Anisian) \\
\hline Porocrinus conicus Billings, 1857 & Porocrinida & Ordovician (Katian) \\
\hline Rhodocrinites verus Miller, 1821 & Diplobathrida & Mississippian (Tournaisian) \\
\hline Rosfacrinus robustus Le Menn and Spjeldnaes, 1996 & Eucamerata & Ordovician (Katian) \\
\hline Synbathocrinus conicus Phillips, 1836 & Disparida & Mississippian (Tournaisian) \\
\hline Taxocrinus macrodactylus (Phillips, 1841) & Flexibilia & Devonian (Famennian) \\
\hline
\end{tabular}

edrioasteroids, such as the isorophids, may be closely related to gogiid eocrinoids, whereas other edrioasteroids, such as Cambraster, may be closer to glyptocystitoid blastozoans and crinoids (Kammer et al., 2013; Zamora et al., 2013; Zamora and Rahman, 2014). Because a comprehensive, up-to-date phylogeny of pentaradiate echinoderm lineages is currently lacking, we 
tentatively follow Guensburg and Sprinkle (2009) and Guensburg et al. (2016) by including both Cambraster and the edrioblastoid Cambroblastus as additional external taxon specifiers.

Identifying synapomorphies of the Clade Crinoidea requires a phylogenetic hypothesis of their position within the broader echinoderm clade. As discussed above, this remains an open question. Basal members of both the Camerata and Pentacrinoidea have a dicyclic calyx with an irregular field of plates intercalating between fixed proximal brachials, suggesting these may be plesiomorphic traits (cf. Apektocrinus, Cnemecrinus, Glenocrinus) (Guensburg, 2012, Ausich et al., 2015; Cole, 2017; Wright, 2017), but a definitive list of shared derived traits cannot be provided here. Moreover, it is challenging to propose a list of apomorphies that unambiguously differentiate crinoids from other echinoderm taxa because many traits are not exclusive to crinoids. Crinoids have been traditionally recognized as distinct from blastozoan-grade echinoderms in having true 'arms,' where arms are defined as coelomic extensions of the body cavity (Sprinkle, 1973). However, morphologic observations of solute and diploporitan echinoderms such as Eumorphocystis and the discovery of various Cambrian 'blastozoans' with arm-like appendages strongly suggest that arms may not be an apomorphy unique to crinoids (Clausen et al., 2009; Zamora and Smith, 2011; Sumrall, 2014; Zamora and Rahman, 2014).

We anticipate future phylogenetic research will help resolve these broader issues in echinoderm phylogeny and evolution. Improved knowledge of relationships among extinct pentaradiate echinoderms may also help refine our definition of the Clade Crinoidea by removing pleonastic external specifiers. We await its refinement.

\section{Camerata Wachsmuth and Springer, 1885}

Definition.-The Camerata is stem-defined as the most inclusive clade containing Actinocrinites triacontadactylus Miller, 1821 and Rhodocrinites verus Miller, 1821 but not Pentacrinites fossilis Blumenbach, 1804.

Remarks.-Camerate crinoids represent a diverse, morphologically distinct 'stem clade' (sensu Sereno, 1999, 2005) ranging from the Lower Ordovician to Permian and contain all taxa traditionally placed within the Diplobathrida and Monobathrida (Moore and Teichert, 1978; Cole, 2017). Camerates are most easily differentiated from pentacrinoids in having calyx plates united by rigid sutures, a heavily plated tegmen surface covering the mouth, and a medial plate (or series of plates) in the posterior (i.e., CD) interray. Unlike pentacrinoids, the camerate posterior plate series has no proximal topographic affinity with the $\mathrm{C}$ ray, although some camerate posterior plates may be homologous with those of pentacrinoids (see Jaekel, 1918, p. 46; Moore and Laudon, 1943; Brower, 1973, p. 301-304; Guensburg and Sprinkle, 2003). In addition, typical camerate species have fixed proximal brachials, interradials, and sometimes intrabrachials, whereas most derived pentacrinoid clades lack these features.

Multiple studies indicate strong support for camerate monophyly (Ausich, 1998b; Ausich et al., 2015; Cole, 2017). However, Cole's (2017) analysis of Ordovician camerates did not find support for a strict division between monocyclic and dicyclic forms. Cole's (2017) phylogenetic revision proposed narrower restrictions on clade membership to render these taxa monophyletic. Following revision, the Monobathrida and Diplobathrida are sister clades that together comprise the more inclusive Eucamerata (Cole, 2017). Thus, the stem-based definition of the Camerata contains the Clade Eucamerata and their stem taxa, including representatives of the oldest known crinoid fossils (e.g., Eknomocrinus, Cnemecrinus), and genera placed within the problematic Reteocrinitidae (see Cole, 2017), and may or may not contain the protocrinoids (see Guensburg and Sprinkle, 2003; Guensburg, 2012; Ausich et al., 2015; Cole, 2017).

\section{Eucamerata Cole, 2017}

Definition.-The Eucamerata is node-defined as the least inclusive clade containing Actinocrinites triacontadactylus Miller, 1821, Rhodocrinites verus Miller, 1821, and Rosfacrinus robustus Le Menn and Spjeldnaes, 1996.

Remarks.-Cole (2017) revised the Monobathrida and Diplobathrida to represent monophyletic groups while attempting to preserve the greatest number of taxa traditionally included within each (Moore and Teichert, 1978). The name 'Eucamerata' was proposed to identify the clade of camerates comprised of the sister groups Monobathrida and Diplobathrida, which necessarily excludes stem taxa such as Cnemecrinus and Reteocrinus (Cole, 2017). The Eucamerata comprise the majority of camerate taxa and span the Ordovician through Permian. Eucamerates are characterized generally by the traits listed above for the Camerata, but differ in typically having more strongly ankylosed calyx plate sutures, primaxils on the second primibrachial, holomeric stems, and pinnulate arms (cf. Actinocrinites and Rhodocrinites with Eknomocrinus and Reteocrinus).

In an attempt to preserve the stability of sister group relationships between monobathrid and diplobathrid clades, we provide a node-based definition for the Eucamerata and stembased definitions for the Monobathrida and Diplobathrida. The internal taxon specifiers Actinocrinites and Rhodocrinites are highly nested constituents of their respective monobathrid and diplobathrid subclades (Moore and Laudon, 1943; Cole, 2017). Rosfacrinus is cautiously included as an additional external specifier because it occupies a somewhat uncertain position at the base of the eucamerate tree (see discussion in Cole, 2017).

Monobathrida Moore and Laudon, 1943

Definition.-The Monobathrida is stem-defined as the most inclusive clade containing Glyptocrinus decadactylus Hall, 1847 and Actinocrinites triacontadactylus Miller, 1821 but not Rhodocrinites verus Miller, 1821 and Archaeocrinus lacunosus (Billings, 1857).

Remarks.-When revising Bather's (1899) polyphyletic division of crinoids into the Monocyclica and Dicyclica, Moore and Laudon (1943) placed all camerates with monocyclic calyces into the Monobathrida. Cole's (2017) phylogenetic analysis of Ordovician camerate crinoids indicates a strict adherence to Moore and Laudon's (1943) concept of the Monobathrida is not monophyletic. However, removal of the stemward camerates 
Eknomocrinus and Adelphicrinus renders the Monobathrida a clade (Cole, 2017). The internal and external specifiers defining this stem-based clade ensure the taxonomic content closely matches Moore and Laudon (1943).

Monobathrids are a taxonomically diverse group of camerates ranging from the Ordovician to Permian and are traditionally diagnosed as monocyclic camerates. Although other clades had similar trends in circlet reduction (e.g., the Disparida), the transformation from a dicyclic to monocyclic calyx likely represents a veritable synapomorphy of monobathrid camerates, as the dicyclic crinoid Gaurocrinus was recovered as the sister taxon to the Monobathrida by Cole (2017). Additional features diagnostic of a typical monobathrid species include having radial plates larger than other calyx plates, an upright basal circlet, an uninterrupted radial circlet (except in the posterior interray), and a posterior interray with anitaxis plating and an anitaxial ridge.

Diplobathrida Moore and Laudon, 1943

Definition.-The Diplobathrida is stem-defined as the most inclusive clade containing Archaeocrinus lacunosus (Billings, 1857) and Rhodocrinites verus Miller, 1821 but not Actinocrinites triacontadactylus Miller, 1821 and Glyptocrinus decadactylus Hall, 1847.

Remarks.-Similar to the discussion above, Moore and Laudon (1943) placed all of Bather's (1899) dicyclic camerate crinoids within the Diplobathrida. As with the monobathrids, Cole's (2017) phylogenetic analysis of Ordovician camerates revealed Moore and Laudon's (1943) Diplobathrida required revision. To achieve monophyly of diplobathrids while retaining much of Moore and Laudon's (1943) taxonomic content, all dicyclic taxa equally related to both monobathrid and diplobathrid camerates sensu Cole (2017) are removed from the Diplobathrida (e.g., Eknomocrinus, Reteocrinids, etc.). Following Cole's (2017) suggested revision, our stem-based definition stabilizes the longheld hypothesis that monobathrids and diplobathrids represent sister clades (Moore and Laudon, 1943; Cole, 2017).

Diplobathrids range from the Ordovician through lower Carboniferous (Serpukhovian). Cole's (2017) discussion on the taxonomic distribution of diplobathrid morphologies suggests they are generally characterized by a combination of character states, including a dicyclic calyx, a concave calyx base either concealing or partially concealing the infrabasal plates, and the presence of additional plates interrupting the radial circlet in all interrays (e.g., Rhodocrinites). Some diplobathrids sensu Cole (2017), such as the Dimerocrinitidae, are similar to monobathrids in having their radial circlet interrupted only in the posterior interray but can easily be distinguished by their dicyclic calyx. A closer examination of post-Ordovician species indicates a substantial revision of subclades within the Diplobathrida is needed and additional research is currently underway (Cole, 2015)

Pentacrinoidea Jaekel, 1918

Definition.-The Pentacrinoidea is stem-defined and as the most inclusive clade containing Apektocrinus ubaghsi Guensburg and Sprinkle, 2009 and Pentacrinites fossilis Blumenbach, 1804 but not Rhodocrinites verus Miller, 1821 and Actinocrinites triacontadactylus Miller, 1821.

Remarks. - The name 'Pentacrinoidea' originates from Jaekel's (1894, 1918) prescient observation that camerate and noncamerate crinoids form distinct clades. Although authors after Jaekel (1918) did not adopt this name in subsequent classifications (see Lane, 1978; Ausich and Kammer, 2001), Jaekel's usage coincides with this strongly supported clade (Guensburg, 2012; Ausich et al., 2015; Cole, 2017; Wright, 2017). Thus, we propose to reinstate the name Pentacrinoidea with the preceding definition.

We have chosen two phylogenetically distant non-camerate species as internal specifiers. Pentacrinites fossilis is a wellknown fossil species from rocks of Jurassic age and is closely related to extant isocrinid crinoids (David et al., 2006), placing it within the Crown Crinoidea (see Articulata below). The species Apektocrinus ubaghsi is a Lower Ordovician fossil and ranks among the stratigraphically oldest known crinoids (Guensburg and Sprinkle, 2009). However, all phylogenetic research indicates it is closer to non-camerates than to camerates and diverges stemward of other basal 'cladid' (sensu Moore and Teichert, 1978) taxa such as Aethocrinus (Guensburg and Sprinkle, 2009; Guensburg, 2012; Ausich et al., 2015; Wright, 2017). Our stem-based definition recognizes Jaekel's (1918) priority of this concept and effectively places all known non-camerate species within the Pentacrinoidea.

Pentacrinoids are a spectacularly diverse and morphologically heterogeneous clade ranging from the Early Ordovician to present-day marine communities. The primary apomorphies differentiating pentacrinoids from camerates relate to their distinctive posterior plating patterns, the degree of calyx plate suturing, and oral region rigidity ('tegmen' terminology here is from Ausich and Kammer, 2016). Posterior plates among pentacrinoids display a proximal relationship with the C-ray radial plate (Guensburg, 2010; Wright, 2015a). Subclades within the Pentacrinoidea express this affinity differently (cf. Cladida and Disparida), and extant crinoids do not retain posterior plates as adults. However, the ontogenetic trajectory of posterior plate development in extant crinoids is tightly linked with morphologic patterns among their Paleozoic precursors (Wright, 2015a). Pentacrinoid calyx plates are less closely sutured (i.e., ankylosed) than camerates and typically have a non-rigid to flexible oral region. In many pentacrinoids, the mouth is directly exposed on the oral surface rather than beneath a tegmen (Ausich and Kammer, 2016).

There are several other morphologic features less diagnostic than those described above but still useful for distinguishing most pentacrinoid species from camerates. For example, some basal pentacrinoids such as Apektocrinus, Aethocrinus, and Alphacrinus incorporate additional plates within the calyx (similar to camerates). However, the overwhelming majority of pentacrinoid clades do not. A major exception occurs among flexible crinoids, but flexibles are a derived group of pentacrinoids and can be differentiated from camerates by other apomorphies (see Flexibilia below). Similarly, eucamerate crinoids have pinnules, but most early to middle Paleozoic pentacrinoids do not. Pinnulation evolved at least once (and probably several times) during the middle to late Paleozoic 
among the subclade Cladida (Wright, 2015b), but these taxa can readily be distinguished from eucamerates in having a pentacrinoid-like posterior plating pattern and free arms above the radials.

\section{Inadunata Wachsmuth and Springer, 1885}

Definition.-The Inadunata is node-defined as the least inclusive clade containing Synbathocrinus conicus Phillips, 1836 and Dendrocrinus longidactylus Hall, 1852.

Remarks.-Wachsmuth and Springer (1885) placed non-articulate fossil crinoids with free arms above the radial plates within the Inadunata. Subsequent classifications divided the Inadunata into the Cladida and Disparida according to the number of circlets in the calyx (Moore and Laudon, 1943; Moore and Teichert, 1978). In a pioneering study on phylogenetic approaches to crinoid classification, Simms and Sevastopulo (1993) pointed out the Inadunata of Moore and Teichert (1978) was paraphyletic and recommended the name be abandoned. In addition, Simms and Sevastopulo's (1993) revision resolved the paraphyly of cladid inadunates by including the Flexibilia and Articulata within the Cladida.

The division between the Camerata and Pentacrinoidea (discussed above) indicates disparids and cladids are more closely related to one another than to camerates (Fig. 2). Indeed, recent phylogenetic analyses of Ordovician crinoids recover a sister group relationship between disparids and cladids (sensu Moore and Laudon, 1943), with hybocrinids nested within the Cladida (Fig. 2) (Guensburg, 2012; Ausich et al., 2015; Wright, 2017). Our definition of the Inadunata combines Wachsmuth and Springer's (1885) original concept with Simms and Sevastopulo's (1993) revision of the Cladida to include flexibles and articulates. Note that this definition places stemward pentacrinoids, such as Apektocrinus, outside the Inadunata. We combine a node-based definition of the Inadunata with stem-based definitions for the subclades Disparida and Cladida to form a node-stem triplet to increase the stability of sister relationships between these taxa (Sereno, 1999).

The Clade Inadunata ranges from the Early Ordovician to the present and are as a whole well characterized by Wachsmuth and Springer's (1885) general concept of crinoids with free arms above the radial plates. Exceptions to this diagnosis occur but are mostly restricted to a few stemward taxa and the Flexibilia, which represent a derived group of inadunates (Springer, 1920).

\section{Disparida Moore and Laudon, 1943}

Definition.-The Disparida is stem-defined as the most inclusive clade containing Synbathocrinus conicus Phillips, 1836 but not Dendrocrinus longidactylus Hall, 1852.

Remarks.-Disparids comprise a diminutive but morphologically and taxonomically diverse clade of fossil crinoids ranging from the Ordovician through Permian. Moore and Laudon (1943) erected the Disparida to include all monocyclic inadunates. Disparid monophyly is well supported by phylogenetic analyses of Ordovician crinoids (Guensburg, 2012;
Ausich et al., 2015; Wright, 2017) and contains all species closer to Synbathocrinus than the cladid Dendrocrinus. Given the similar topologies across these studies, the Clade Disparida retains taxa traditionally placed within disparids (sensu Moore and Laudon, 1943) except for the hybocrinids.

A major synapomorphy and useful diagnostic trait of disparid crinoids is the presence of a single circlet of plates below the radials. All other pentacrinoids are either dicyclic (cladids), pseudomonocyclic (hybocrinids) (see Sprinkle, 1982b), or otherwise phylogenetically distant from disparids (some derived articulates may not develop infrabasals, see Lahaye and Jangoux, 1987). Disparids also have simple or compound radial plates, typically lack pinnules, and have approximate bilateral symmetry between rays oriented in one of several possible planes (see Moore et al., 1978b). As pentacrinoids, disparids have posterior plates in a proximal position to the $\mathrm{C}$ ray but differ from cladids in having plates positioned above rather than below or in line with the C-ray radial plate. However, posterior plate homologies among disparids and between inadunate clades are presently obscured by a set of descriptive terms opaque to homology. Whether the proximal C-ray posterior plate is an anibrachial,' a 'radianal,' an 'anal X,' a 'superradial,' or a 'radial' is uncertain (Moore, 1962; Moore and Teichert, 1978; Ausich, 1996). Future work is needed to help clarify primary posterior plate homologies among disparids and between cladids and disparids. The results of Wright's (2017) analysis of Ordovician through Devonian pentacrinoid taxa support Guensburg's (2010) assessment of Alphacrinus as a lower Tremadocian crinoid phylogenetically close to the base of the disparid clade. Guensburg (2010) considered the posterior of Alphacrinus to express a transitional form between 'typical' pentacrinoid posterior plates and the ray-like extensions common among disparid taxa. A re-examination of the posterior interray of basal taxa combined with studies on disparid ontogeny may help resolve this issue.

Cladida Moore and Laudon, 1943

Definition.-The Cladida is stem-defined as the most inclusive clade containing Dendrocrinus longidactylus Hall, 1852 but not Synbathocrinus conicus Phillips, 1836.

Remarks. - The Cladida were originally defined by Moore and Laudon (1943) to comprise a tremendously diverse and longranging (Ordovician-Triassic) assemblage of dicyclic inadunates with their mouths covered with primary peristomial cover plates (Ausich and Kammer, 2016). Moore and Laudon's (1943) original concept and taxonomic content of the Cladida is paraphyletic, as they agreed with Springer's (1920) earlier assessment that flexible crinoids were more closely related to some cladids than others but did not place the Flexibilia within the Cladida. Moreover, post-Paleozoic crinoids within Miller's (1821) Articulata have long been considered descendants of Paleozoic cladids (Jaekel, 1918; Moore et al., 1952; Rassmussen, 1978; Simms, 1988). Simms and Sevastopulo (1993) conducted a cladistic analysis of Paleozoic cladids, flexibles, and articulate crinoids and subsequently remedied cladid paraphyly by placing the Flexibilia and the Articulata within the Cladida (sensu Moore and Laudon, 1943). Although many authors have 
followed Simms and Sevastopulo's (1993) interpretation of relationships among these taxa, only a few authors have since followed their revised rank-based classification (e.g., Brower, 2001, 2002; Donovan and Harper, 2003).

Our stem-based definition of the Cladida is similar in taxonomic content to Simms and Sevastopulo's (1993) because it includes all species closer to Dendrocrinus than to the disparid Synbathocrinus. Thus, the Cladida spans the Ordovician to the Recent and contains the major subclades Porocrinoidea, Flexibilia, and Articulata. Cladids are most easily distinguished from their sister group, the Disparida, in typically having a dicyclic calyx and posterior plates (as adults or during development) located below and/or in line with the radial plate circlet (Wright, 2015a). Lastly, many middle Paleozoic to Recent cladids have pinnules, whereas most disparids do not (Frest et al., 1979).

\section{Porocrinoidea Wright, 2017}

Definition.-The Porocrinoidea is node-defined as the least inclusive clade containing Carabocrinus radiatus Billings, 1857 and Hybocrinus conicus Billings, 1857.

Remarks.-In their description of crinoids belonging to Bather's (1899) 'Cyathocrinina', Moore and Laudon (1943) speculated that 'primitive' cyathocrinids such as Carabocrinus might be closely related to the enigmatic taxon Hybocrinus. Sprinkle (1982b) argued the stem and calyx morphology of Hybocrinus suggested hybocrinids were 'pseudomonocyclic' and listed a number of characters linking hybocrinids with cladids. Although hybocrinids have not traditionally been classified within the Cladida, many phylogenetic analyses of Ordovician crinoids have recovered a clade of 'cyathocrine' grade cladids and hybocrinids (Guensburg, 2012; Ausich et al., 2015; Wright, 2017). Wright's (2017) phylogenetic analysis of Ordovician through Devonian pentacrinoids recovered a clade comprised of Porocrinus, Carabocrinus, and the hybocrinids Hybocrinus and Hybocystites. Notably, this clade is stemward of the split between flexible and other cladid crinoids. Thus, Wright (2017) proposed the name 'Porocrinoidea' to encompass this early diverging and morphologically unique clade of Ordovician crinoids.

Our node-based definition of the Porocrinoidea sets up a node-stem triplet that stabilizes the sister clade relationship among the Porocrinida and Hybocrinida recovered by Ausich et al. (2015), which had denser taxon sampling of Ordovician crinoids than Wright (2017). The Clade Porocrinoidea is likely limited to the Ordovician Period, but additional analyses sampling younger species are needed to test the extent of their geologic duration. Porocrinoids are a subclade of cladids characterized by globose, conical, or ovate calyces that possess a number of apomorphies convergent with blastozoan echinoderms, such as having thecal respiratory structures, reduction in arm number and calyx plates, and/or recumbent ambulacra (see Moore and Teichert, 1978; Sprinkle, 1982a, 1982b).

\section{Porocrinida Miller and Gurley, 1894}

Definition.-The Porocrinida is stem-defined as the most inclusive clade containing Porocrinus conicus Billings, 1857 and Carabocrinus radiatus Billings, 1857 but not Hybocrinus conicus Billings, 1857.

Remarks.-The Porocrinida comprise a small clade of Ordovician porocrinoids with apomorphic endothecal and/or exothecal respiratory structures. Sprinkle (1982a) pointed to many similarities among Carabocrinus, Palaeocrinus, and the Porocrinidae and hypothesized they may be closely related. Ausich et al. (2015) recovered a topology supporting this hypothesis with the euspirocrinid Illemocrinus as their sister taxon. However, Wright (2017) recovered Euspirocrinus outside the porocrinid clade within a different clade of "cyathocrine' grade cladids. Thus, Illemocrinus is tentatively placed within the Porocrinida, but other taxa within the Euspriocrinidae should not be placed within the Porocrinida at this time as additional revisions are necessary. Guensburg (2012) recovered a similar tree to Ausich et al. (2015) that suggested Perittocrinus may be also be a porocrinid.

The stem-based definition of the Porocrinida makes them sister to the Hybocrinida and retains the taxonomic membership of this clade recovered in Ausich et al. (2015) and Guensburg (2012). Porocrinids can easily be distinguished from hybocrinids in having a dicyclic calyx and the presence of thecal respiratory structures (Kesling and Paul, 1968; Sprinkle, 1982a).

$$
\text { Hybocrinida Jaekel, } 1918
$$

Definition.-The Hybocrinida is stem-defined as the most inclusive clade containing Hybocrinus conicus Billings, 1857 and Hybocystites problematicus Wetherby, 1880 but not Porocrinus conicus Billings, 1857 and Carabocrinus radiatus Billings, 1857.

Remarks.-Hybocrinids comprise a small yet morphologically disparate clade of Ordovician crinoids. Although the monocyclic hybocrinids have been either considered disparids or classified outside the Inadunata (Moore and Laudon, 1943; Moore and Teichert, 1978; Ausich, 1998b), Sprinkle (1982b) suspected hybocrinids might be 'pseudomonocyclic' and potentially related to 'cyathocrine' cladids (see Sprinkle, 1982a, 1982b). Phylogenetic analyses by Guensburg (2012), Ausich et al. (2015), and Wright (2017) all support the monophyly of the Hybocrinida and their sister group relationship with taxa placed in the Porocrinida (see Sprinkle, 1982b).

In addition to having a pseudomonocyclic calyx (infrabasals absent), hybocrinids are characterized by a number of unusual apomorphies that distinguish them from Porocrinids (and all other crinoids). Many of these traits are similar to those typically present in blastozoan echinoderms, including reduction in the number of arms, modification of food-gathering appendages to be recumbent (sometimes extending downward over calyx plates), and reduction in the number of calyx plates (Sprinkle and Moore, 1978).

\section{Flexibilia Zittel, 1895}

Definition.-The Flexibilia is stem-defined as the most inclusive clade containing Taxocrinus macrodactylus (Phillips, 1841) but not Dendrocrinus longidactylus Hall, 1852. 
Remarks.-Flexible crinoids are a morphologically homogeneous clade that originated sometime during the Middle to Late Ordovician and range through the Permian. Springer $(1911,1920)$ was the first to recognize that flexible crinoids were closely related to inadunates. In his comprehensive 1920 monograph, The Crinoidea Flexibilia, Springer compared morphologic characteristics of the inadunate Cupulocrinus with the earliest known flexible Protaxocrinus, citing numerous similarities in calyx plating, interradial areas, and the arrangement of posterior plates. Springer (1920) concluded Cupulocrinus was potentially a transitional fossil that linked inadunates with flexibles, stating, "there is clearly an intermingling of the characters ... and it is evident that in Cupulocrinus we have to deal with a transition [sic] form whose exact status is difficult to decide" (Springer, 1920, p. 89). Subsequent taxonomic treatments have also recognized Cupulocrinus as occupying a proximal position to the base of the flexible tree (Moore and Laudon, 1943; Moore and Teichert, 1978).

Phylogenetic analyses sampling flexible and other crinoid taxa have invariably recovered tree topologies supporting Springer's $(1911,1920)$ hypothesis, with Cupulocrinus recovered as the sister taxon to the Flexibilia (Brower, 1995, 2001; Ausich, 1998b; Ausich et al., 2015; Wright, 2017). Wright's (2017) analysis used Bayesian methods to estimate the probability of Cupulocrinus being ancestral (sensu Foote, 1996) to the flexible clade. Results strongly support Cupulocrinus as occupying an ancestral position (posterior probability = 0.99) (Wright, 2017). Given these results and our stem-based definition of the Flexibilia, species of Cupulocrinus are now placed within the flexibles.

Flexible crinoids have loosely sutured calyx plating and a remarkably uniform set of apomorphies relative to other crinoid clades. For example, flexibles differ from cladids in having interradial and intrabrachial plates and differ from other dicyclic crinoids in typically having their lowermost circlet comprised of three (rather than five) infrabasal plates. One infrabasal plate, the 'azygous', is smaller than the other two, and is located in the $\mathrm{C}$ ray (except for the derived Forbesiocrinus). Many flexibles retain posterior plate arrangements similar to other cladids, but posterior plates are sometimes absent in more derived flexibles. In contrast with cladids, arms of flexible crinoids are universally uniserial and lack pinnules, and the stem is nearly always transversely circular (Springer, 1920).

\section{Eucladida Wright, 2017}

Definition.-The Eucladida is stem-defined as the most inclusive clade containing Dendrocrinus longidactylus Hall, 1952 and Pentacrinites fossilis Blumenbach, 1804 but not Taxocrinus macrodactylus (Phillips, 1841).

Remarks. - The revision of the Cladida to be monophyletic requires placing the subclades Porocrinoidea, Flexibilia, and Articulata within a more inclusively defined Clade Cladida (Simms and Sevastopulo, 1993; Wright, 2017). However, the Cladida (sensu Moore and Laudon, 1943) is traditionally conceived as a Paleozoic-age paraphyletic group that excludes the Flexibilia. The Eucladida was proposed by Wright (2017) to comprise all species within the Clade Cladida sharing a more recent common ancestor with Dendrocrinus and Pentacrinites than with Taxocrinus. Thus, the stem-defined clades Flexibilia and Eucladida are sister to one another and articulates are nested within the Eucladida. This Eucladida retains much of the meaning and taxonomic content of Moore and Laudon's (1943) concept for Paleozoic cladids while eschewing paraphyly.

In the Treatise on Invertebrate Paleontology, Moore et al. (1978a) recognized three rank-based taxa within the Cladida: the Dendrocrinida, the Cyathocrinida, and the Poteriocrinida. However, it has long been questioned whether these taxa represent monophyletic groups (McIntosh, 1986, 2001; Sevastopulo and Lane, 1988; Kammer and Ausich, 1992, 1996; Simms and Sevastopulo, 1993; Wright, 2015a, 2015b; Wright, and Ausich, 2015). Indeed, the Poteriocrinida is depicted in the Treatise as a polyphyletic group (Moore et al., 1978a, fig. 412). A phylogenetic analysis of Ordovician through Devonian pentacrinoids by Wright (2017) has confirmed the doubts over the monophyly of these taxa. Much of the problem arises from ambiguous and/or uninformative apomorphies chosen for these taxa that perpetuate taxonomic anarchy via 'undiagnostic diagnoses' (Wright, 2015b; see Lane, 1978, p. T295). Although much revision is needed, recent analyses indicate there is nevertheless considerable phylogenetic structure among subclades of Paleozoic cladids, and additional work is under way to revise this diverse group (Wright, 2015b).

\section{Articulata Miller, 1821}

Definition.-The Articulata is node-defined as the least inclusive clade containing Endoxocrinus parrae (Gervais, 1835) and Antedon bifida (Pennant, 1777).

Remarks.-The Articulata was proposed by Miller (1821) and has since developed a longstanding reputation as a problematic group that lacks a concise and unambiguous definition (Rasmussen, 1978; Simms, 1988; Simms and Sevastopulo, 1993; Webster and Jell, 1999; Rouse et al., 2013). Although all extant crinoids are invariably recognized as articulates, much confusion surrounds the recognition of fossil articulates and the timing of their origin. The primary difficulties surround which apomorphy (or combination of apomorphies) is useful for diagnosing the Articulata. For example, it is widely appreciated that no apomorphy or unique set of apomorphies can presently diagnose fossil articulates without ambiguity (Simms, 1988; Simms and Sevastopulo, 1993; Webster and Jell, 1999; Rouse et al., 2013). Most crinoid workers have obviated this problem by simply treating the Articulata as synonymous with postPaleozoic crinoids (see Simms and Sevastopulo, 1993). However, this usage is problematic because this definition is not based on any explicit phylogenetic hypothesis. Moreover, many Paleozoic groups of fossil cladids share different combinations of traits typically listed as 'diagnostic' for the Articulata (Webster and Jell, 1999; Webster and Lane, 2007). If the concept of what defines the Articulata depends on the choice of a particular combination of apomorphies alone, then questions regarding the 'origin of the Articulata' will always depend on which specific combination was chosen a priori to be diagnostic. Without a phylogenetic definition, it is impossible to objectively specify a precise set of synapomorphies for the Articulata. Thus, 
we propose herein to define the Articulata as the crinoid crown group containing the last common ancestor of the extant isocrinid Endoxocrinus parrae and the comatulid Antedon bifida, and all of its descendants.

As discussed by Ruta et al. (2003), the concepts of stem groups and crown groups are sometimes misinterpreted or misused in the paleontological literature. Used properly, crown groups are defined by extant taxon specifiers. Notably, crown groups may be comprised of many (or mostly) extinct fossil species. For example, if a fossil crinoid is more closely related to some extant species than others, it is a member of the crown group. According to Rouse et al. (2013), the most recent common ancestor of all extant crinoids lived sometime during the Middle to Upper Triassic. Thus, our node-based definition eliminates the non-phylogenetic concept of 'post-Paleozoic Crinoidea' while retaining the majority of post-Paleozoic crinoids traditionally included within the Articulata. The Clade Articulata is synonymous with the Crown Crinoidea (Sumrall, 2014), and we advocate workers use these terms interchangeably depending on context (e.g., discussing relationships among crinoids or between crinoids and non-crinoids). Traits that may be present in the Articulate ancestor are listed in Simms (1988), Simms and Sevastopulo (1993), Webster and Jell (1999), and Rouse et al. (2013).

The Articulata likely contains most post-Paleozoic taxa traditionally considered articulates, including the $\sim 600$ or so extant species. Although we define Articulata with precision and phylogenetic stability (Rouse et al., 2013, 2015), it remains difficult in practice to unambiguously identify fossil articulates, particularly among specimens near the base of the articulate tree. However, such difficulties are already present and have long obfuscated the origin of the crinoid crown group. The more important problem is resolving the phylogenetic position of the common ancestor of extant crinoids within the myriad of fossil lineages. Our definition provides a useful framework for future phylogenetic research to uncover relationships between potential stem articulates, extinct crown group lineages, and extant species.

\section{A revised rank-based classification of the Crinoidea}

Crinoid clades identified herein confirm many long-held views on the major divisions among crinoids from both the foundational work of Moore and Laudon (1943) and Moore and Teichert (1978) to more recent analyses (i.e., Ausich, 1998a, 1998b; Guensburg and Sprinkle, 2003; Guensburg, 2012; Ausich et al., 2015). Results from all of these studies recognized the Camerata, Diplobathrida, Monobathrida, Hybocrinida, Disparida, Cladida, and Flexibilia. The challenge is to represent these widely recognized clades in a rank-based Linnaean classification scheme that maximizes common usages of names for crinoid lineages (Moore and Teichert, 1978) and is consistent with a phylogenetic understanding of relationships (Wiley and Lieberman, 2011). In our revision, the Crinoidea remain a class and every attempt is made to retain orders as recognized in Moore and Teichert (1978). Unfortunately, the tree topology of Figure 2 prevented the attainment of the latter in all instances, but the addition of intermediate Linnaean ranks makes it easier to apply a phylogenetic perspective to rank-based crinoid classification. The use of intermediate ranks (e.g., Parvclass) follows traditional use in pre-existing taxonomic literature (see Carroll, 1988; Sibley, 1994; Benton, 2005). Two older taxonomic names, the Pentacrinoidea Jaekel, 1918 and Inadunata Wachsmuth and Springer, 1885, are formally reinstated herein because they represent meaningful clades as described above.

Post-Ordovician cladids (sensu Moore and Laudon, 1943) and the Protocrinoida (Guensburg and Sprinkle, 2003) remain problematic groups. Because the rank for a monophyletic Cladida must be above flexibles and articulates (Simms and Sevastopulo, 1993), we propose the name Cyathoformes to contain taxa traditionally placed within the Cladida that are sister to the Articulata. Relationships among these taxa are the subject of future phylogenetic research (Wright, 2015b) and are not treated further here. From their initial description (Guensburg and Sprinkle, 2003), the protocrinoids have been an important but confounding group of crinoids that display characteristics of both crinoids and other stalked echinoderms. Guensburg and Sprinkle (2003) regarded the protocrinoid as an "order (plesion)". The validity of the protocrinoids was later questioned by Guensburg and Sprinkle (2009) and led Guensburg (2012) to formally place them within the Camerata. However, Ausich et al. (2015) recovered a sister group relationship between Titanocrinus and Glenocrinus, but with protocrinoids more closely related to non-camerates than camerates. In contrast, Cole's (2017) analysis of Ordovician crinoids recovered the protocrinoids as more closely related to camerates than non-camerates. Thus, we have carefully chosen our clade definitions to not depend on a particular phylogenetic hypothesis or morphologic interpretation of these significant but problematic taxa. For the moment, we tentatively place both protocrinoid taxa as Crinoidea incertae sedis subclass Protocrinoida.

In our present understanding of crinoid evolution, the first major divergence occurs between camerates and all other crinoids (Fig. 2). The subclass rank is retained for the Camerata; and the subclass Pentacrinoidea Jaekel, 1918 is proposed for its sister group (Table 2). Within the Camerata, the orders Diplobathrida and Monobathrida are retained as sister groups, and the infraclass Eucamerata Cole (2017) unites these two orders. In phylogenetic analyses of camerates, several taxa are not placed within the Monobathrida and Diplobathrida (sensu Cole, 2017). Thus, they are considered here to be stem eucamerates (see remarks for Eucamerata above). The subclass Camerata unites these stem taxa with eucamerates.

In terms of species richness, the subclass Pentacrinoidea is the largest crinoid clade. This includes the Disparida, Cladida, Hybocrinida, and Articulata of Moore and Teichert (1978), which coincides exactly with Jaekel's (1918) concept of the Pentacrinoidea (see Lane, 1978). Hence, we have proposed the reinstatement of this name. The Pentacrinoidea is comprised of the infraclass Inadunata and their stem taxa (e.g., Apektocrinus). The concept for the Inadunata in Moore and Teichert (1978) united the Disparida and the Cladida. Here, the infraclass Inadunata unites the Disparida, Cladida, and all of their descendants. This usage circumvents the non-phylogenetic usage of the Inadunata (sensu Moore and Teichert, 1978) and is consistent with the phylogenetic conclusions of Simms and 
Table 2. Revised rank-based classification of the Crinoidea.

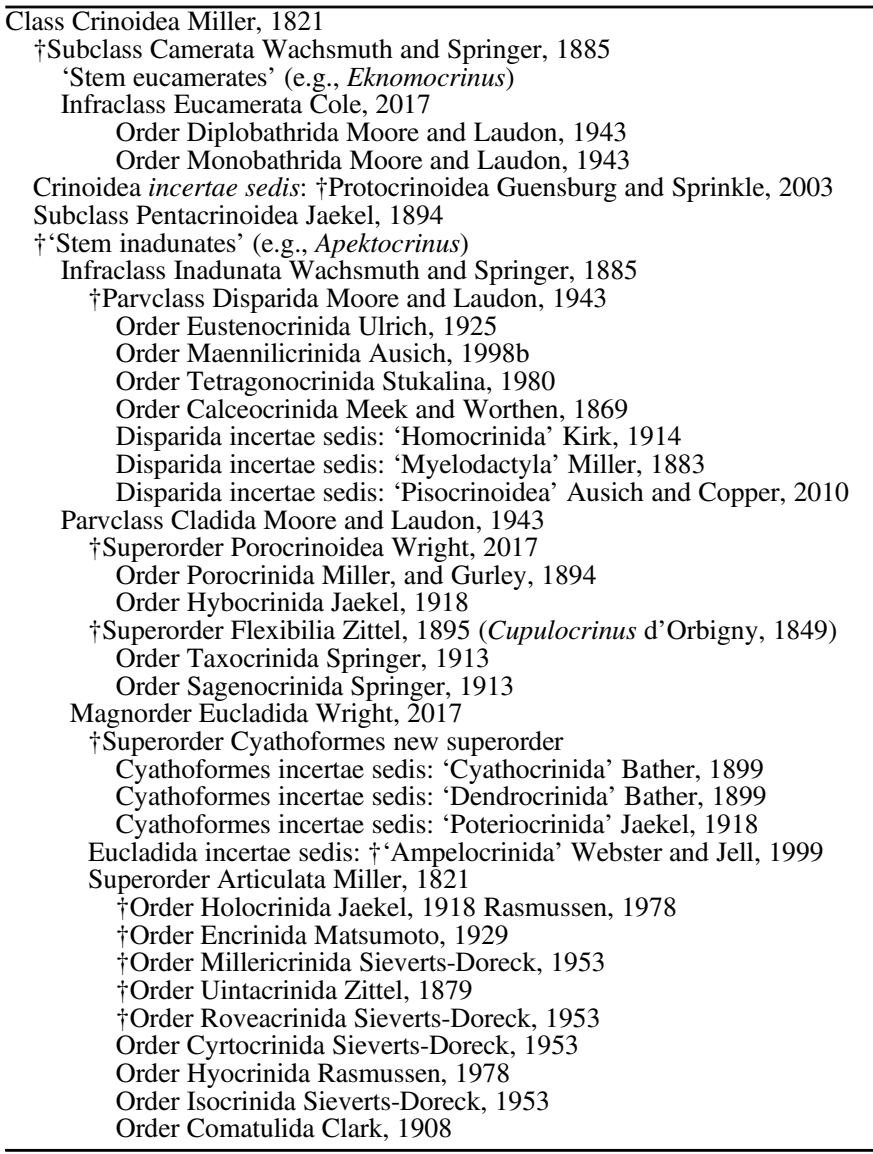

Sevastopulo (1993). With the Inadunata an infraclass, the Disparida and Cladida are both parvclasses. Taxa placed within the Disparida are in need of revision, and current work is underway to establish relationships among sublcades (Ausich and Donovan, 2015).

Within the Cladida, the Hybocrinida, Porocrinida, Taxocrinida Springer, 1913 and Sagenocrinida Springer, 1913 are orders (Table 2). The orders Hybocrinida and Porocrinida are sister groups forming the superorder Porocrinoidea Wright (2017). The Flexibilia are transferred to the superorder rank, which is comprised of the two sister groups, order Taxocrinida and order Sagenocrinida. The Cyathoformes and Articulata comprise the magnorder Eucladida (Wright, 2017). The Eucladida retains most cyathocrinids, dendrocrinids, and poteriocrinids of Moore and Teichert (1978). As discussed above, phylogenetic relationships within this clade await further study (Wright, 2015b). Analyses detailing the late Paleozoic and early Mesozoic crinoid phylogeny are needed to understand this crucial period of crinoid evolution. Lastly, the Articulata is considered a superorder within the Cladida.

\section{Conclusions}

A phylogeny-based revision of crinoid systematics is proposed to clarify the definition of clades and inform a major revision of the rank-based Linnaean classification. These revisions are based on recent computational phylogenetic analyses that build on the historic subdivision of crinoids into major lineages. It is hoped that the phylogenetic classification schemes presented herein will help provide a framework for future research on crinoid phylogeny and offer guidance to crinoid workers and non-specialists alike interested in using this fascinating group of echinoderms to study evolutionary patterns and processes.

\section{Acknowledgments}

We thank the organizing committee of the 2015 Progress in Echinoderm Paleobiology conference and guest editors S. Zamora and I.A. Rahman for inviting us to submit this contribution. G.D. Sevastopulo and an anonymous reviewer are thanked for their helpful reviews and useful comments. I.A. Rahman provided careful editorial assistance and made several suggestions that improved the manuscript. This research was supported by grants from numerous organizations, including the National Science Foundation (DEB 1036416, WIA), the Paleontological Society's N.G. Lane award (DFW, SRC), Sigma Xi (DFW, SRC), Palaeontological Association (DFW, SRC), the American Federation of Mineralogical and Geological Societies Student Scholarship (DFW, SRC), and The Ohio State University School of Earth Sciences' Friends of Orton Hall Scholarship (DFW, SRC). DFW was also supported by an Ohio State University Presidential Fellowship.

\section{References}

Alaniz, R.J., 2014, Dredging evolutionary theory: The emergence of the deep sea as a transatlantic site for evolution 1853-1876 [Ph.D. dissertation]: San Diego, University of California, $360 \mathrm{p}$.

Angelin, N.P., 1878, Iconographia Crinoideorum in stratis Sueciae Siluricis fossilium: Holmiae, Samson and Wallin, $62 \mathrm{p}$.

Ausich, W.I., 1980, A model for niche differentiation in Lower Mississippian crinoid communities: Journal of Palontology, v. 54, p. 273-288.

Ausich, W.I., 1986, Early Silurian rhodocrinitacean crinoids (Brassfield Formation, Ohio): Journal of Paleontology, v. 60, p. 84-106.

Ausich, W.I., 1996, Crinoid plate circlet homologies: Journal of Paleontology, v. 70, p. 955-964.

Ausich, W.I., 1998a, Early phylogeny and subclass division of the Crinoidea (phylum Echinodermata): Journal of Paleontology, v. 72, p. 499-510.

Ausich, W.I., 1998b, Phylogeny of Arenig to Caradoc Crinoids (Phylum Echinodermata) and suprageneric classification of the Crinoidea: The University of Kansas Paleontological Contributions Papers, New Series, no. v. 9, 36 p.

Ausich, W.I., and Babcock, L.E., 1998, The phylogenetic position of Echmatocrinus brachiatus, a probable octocoral from the Burgess Shale: Palaeontology, v. 41, p. 193-202.

Ausich, W.I., and Bottjer, D.J., 1982, Tiering in suspension-feeding communities on soft substrata throughout the Phanerozoic: Science, v. 216, p. 173-174.

Ausich, W.I., and Copper, P., 2010, The Crinoidea of Anticosti Island, Québec: (Late Ordovician to early Silurian): Palaeontographica Canadiana, v. 29,157 p.

Ausich, W.I., and Donovan, S.K., 2015, Phylogeny of disparid crinoids: Geological Society of America Abstracts with Programs, v. 47, p. 855.

Ausich, W.I., and Kammer, T.W., 2001, The study of crinoids during the 20th century and the challenges of the 21st century: Journal of Paleontology, v. 75 , p. $1161-1173$.

Ausich, W.I., and Kammer, T.W., 2008, Generic concepts in the Amphoracrinidae Bather, 1899 (Class Crinoidea) and evaluation of generic assignments of North American species: Journal of Paleontology, v. 82, p. $1139-1149$.

Ausich, W.I., and Kammer, T.W., 2016, Exaptation of pelmatozoan oral surfaces: Constructional pathways in tegmen evolution: Journal of Paleontology, v. 90, p. 689-720. doi: 10.1017/jpa.2016.73.

Ausich, W.I., Kammer, T.W., and Baumiller, T.K., 1994, Demise of the middle Paleozoic crinoid fauna: A single extinction event or rapid faunal turnover? Paleobiology, v. 20, p. 345-361. 
Ausich, W.I., Kammer, T.W., Rhenberg, E.C., and Wright, D.F., 2015, Early phylogeny of crinoids within the Pelmatozoan clade: Palaeontology, v. 58, p. 937-952.

Bassler, R.S., 1943, New Ordovician cystidean echinoderm from Oklahoma: American Journal of Science, v. 241, p. 694-703.

Bather, F.A., 1898, Wachsmuth and Springer's classification of crinoids: Natural Science, v. 12 , p. 337-345.

Bather, F.A., 1899, A phylogenetic classification of the Pelmatozoa: British Association for the Advancement of Science, v. 1898, p. 916-923.

Bather, F.A., 1900, Part III The Echinoderma. The Pelmatozoa, in Lankester, E.R., ed., A Treatise on Zoology: London, Adam and Charles Black, p. 94-204.

Baumiller, T.K., 2008, Crinoid ecological morphology: Annual Review of Earth and Planetary Sciences, v. 36, p. 221-249.

Benton, M.J., 2000, Stems, nodes, crown clades, and rank-free lists: Is Linnaeus dead?: Biological Reviews of the Cambridge Philosophical Society, v. 75 , p. 633-648.

Benton, M.J., 2005, Vertebrate Paleontology (third edition): Oxford, Blackwell Publishing, $472 \mathrm{p}$

Benton, M.J., 2007, The Phylocode: Beating a dead horse?: Acta Palaeontologica Polonica, v. 52, p. 651-655.

Billings, E., 1857, New species of fossils from Silurian rocks of Canada: Canada Geological Survey, Report of Progress 1853-1856, Report for the year 1856 , p. $247-345$

Blumenbach, J.F., 1802-1804, Abbildungen naturhistorischer Gegenstände: Gottingen, Heinrich Dieterich, pt. 70, no, 70, 4 p.

Branson, E.B., and Peck, R.E., 1940, A new cystoid from the Ordovician of Oklahoma: Journal of Paleontology, v. 14, p. 89-92.

Brochu, C.A., 2003, Phylogenetic approaches toward crocodylian history: Annual Review of Earth and Planetary Sciences, v. 31, p. 357-397.

Brochu, C.A., and Sumrall, C.D., 2001, Phylogenetic nomenclature and paleontology: Journal of Paleontology, v. 75, p. 754-757.

Brower, J.C., 1973, Crinoids from the Girardeau Limestone (Ordovician): Palaeontographica Americana, v. 7, p. 263-499.

Brower, J.C., 1995, Dendrocrinid crinoids from the Ordovician of northern Iowa and southern Minnesota: Journal of Paleontology, v. 69, p. 939-960.

Brower, J.C., 2001, Flexible crinoids from the Upper Ordovician Maquoketa Formation of the northern midcontinent and the evolution of early flexible crinoids: Journal of Paleontology, v. 75, p. 370-382.

Brower, J.C., 2002, Cupulocrinus angustatus (Meek and Worthen, 1870), A cladid crinoid from the Upper Ordovician Maquoketa Formation of the northern midcontinent of the United States: Journal of Paleontology, v. 76, p. $109-122$.

Butler, R.J., Upchurch, P., and Norman, D.B., 2008, The phylogeny of the ornithischian dinosaurs: Journal of Systematic Palaeontology, v. 6, p. 1-40

Cantino, P.D., and de Queiroz, K., 2010, PhyloCode: International code of phylogenetic nomenclature, version $4 \mathrm{c}, 90 \mathrm{p}$.

Carlson, S.J., 2001, Ghosts of the past, present, and future in brachiopod systematics: Journal of Paleontology, v. 75, p. 1109-1118.

Carlson, S.J., and Leighton, L.R., 2001, The phylogeny and classification of Rhynchonelliformea: The Paleontological Society Special Papers, v. 7, p. 27-51

Carroll, R.L., 1988, Vertebrate Paleontology and Evolution: New York, WH Freeman, $698 \mathrm{p}$

Clark, A.H., 1908, Description of new species of crinoids, chiefly from the collections made by U.S. Fisheries steamer "Albatross" at the Hawaiian Islands in 1902, with remarks on the classification of the Comatulida: Proceedings of the U.S. National Museum, v. 34, p. 209-239.

Clark, A.H., 1915, A monograph of the existing crinoids, part 1: Bulletin of the United States National Museum, v. 82, p. 1-406.

Clark, A.H., 1921, A monograph of existing crinoids, part 2: Bulletin of the United States National Museum, v. 82, p. 1-795.

Clark, A.H., and Clark, A.M., 1967, A monograph of existing crinoids, part 5: Bulletin of the United States National Museum, v. 82, p. 1-806.

Clausen, S., Jell, P.A., Legrain, X., and Smith, A.B., 2009, Pelmatozoan arms from the middle Cambrian of Australia: Bridging the gap between brachioles and brachials?: Lethaia, v. 42, p. 283-296.

Cohen, B.L., Ameziane, N., Eleaume, M., and de Forges, B.R., 2004, Crinoid phylogeny: A preliminary analysis (Echinodermata: Crinoidea): Marine Biology, v. 144, p. 605-617.

Cole, S.R., 2015, A phylogenetic test of the suprageneric classification of diplobathrid crinoids: Geological Society of America Abstracts with Programs, v. 47, p. 853.

Cole, S.R., 2017, Phylogeny and morphologic evolution of the Ordovician Camerata (Class Crinoidea, Phylum Echinodermata): Journal of Paleontology, doi: 10.1017/jpa.2016.137.

Darwin, C., 1859, On the origin of species by means of natural selection: London, Murray, $502 \mathrm{p}$.

David, B., Lefebvre, B., Mooi, R., and Parsley, R., 2000, Are homalozoans echinoderms? An answer from extraxial-axial theory: Paleobiology, v. 26, p. $529-555$.
David, B., Roux, M., Messing, C.G., and Ameziane, N., 2006, Revision of the pentacrinid stalked crinoids of the genus Endoxocrinus (Echinodermata, Crinoidea), with a study of environmental control characters and its consequences for taxonomy: Zootaxa, v. 1156, p. 1-50.

Deline, B., and Ausich, W.I., 2011, Testing the plateau: A reexamination of disparity and morphologic constraints in early Paleozoic crinoids: Paleobiology, v. 37, p. 214-236.

de Queiroz, K., and Gauthier, J., 1990, Phylogeny as a central principle in taxonomy: Phylogenetic definitions of taxon names: Systematic Biology, v. 39 , p. $307-322$

de Queiroz, K., and Gauthier, J., 1992, Phylogenetic taxonomy: Annual Review of Ecology and Systematics, v. 23, p. 449-480.

de Queiroz, K., and Gauthier, J., 1994, Toward a phylogenetic system of biological nomenclature: Trends in Ecology and Evolution, v. 9, p. 27-31.

Donovan, S.K., 1988, The early evolution of the Crinoidea, in Paul, C.R.C., and Smith, A.B., eds. Echinoderm Phylogeny and Evolutionary Biology: Oxford, Clarendon Press, p. 235-244.

Donovan, S.K., and Harper, D.A.T., 2003, Llandovery crinoidea of the British Isles, including description of a new species from the Kilbride Formation (Telychian) of western Ireland: Geological Journal, v. 38, p. 85-97.

d'Orbigny, A.D., 1849, Cours élémentaire de paléontologie et géologie Stratigraphiques, v. Volume 1: Paris, Victor Masson, 299 p.

Eichwald, E. von, 1840, Ueber das Silurische Schichtensystem in Ethlands: St. Petersburg, 200 p.

Etter, W., and Hess, H., 2015, Reviews and syntheses: The first records of deep-sea fauna-a correction and discussion: Biogeosciences, v. 12, p. 6453-6462.

Feuda, R., and Smith, A.B., 2015, Phylogenetic signal dissection identifies the root of starfishes: PLoS ONE, 10.5, e0123331.

Foote, M., 1996, On the probability of ancestors in the fossil record: Paleobiology, v. 22, p. 141-151.

Foote, M., 1999, Morphological diversity in the evolutionary radiation of Paleozoic and post-Paleozoic crinoids: Paleobiology, v. 25, p. 1-115.

Foote, M., and Raup, D.M., 1996, Fossil preservation and the stratigraphic ranges of taxa: Paleobiology, v. 22, p. 121-140.

Foote, M., and Sepkoski, J.J., 1999, Absolute measures of the completeness of the fossil record: Science, v. 398, p. 415-417.

Forey, P.L., Fortey, R.A., Kenrick, P., and Smith, A.B., 2004, Taxonomy and fossils: A critical appraisal: Philosophical Transactions of the Royal Society of London B: Biological Sciences, v. 359, p. 639-653.

Frest, T.J., Strimple, H.L., and McGinnis, M.R., 1979, Two new crinoids from the Ordovician of Virginia and Oklahoma, with notes on pinnulation in the Disparida: Journal of Paleontology, v. 53, p. 399-415.

Gahn, F.J., and Kammer, T.W., 2002, The cladid crinoid Barycrinus from the Burlington Limestone (early Osagean) and the phylogenetics of Mississippian botryocrinids: Journal of Paleontology, v. 76, p. 123-133.

Gervais, F.L.P., 1835, Encrines, in Guérin, ed., Dictionnaire pittoresque d'histoire naturelle et des phénomènes de la nature, v. 3: Paris, Lenormand, p. 48-49.

Goldfuss, G.A., 1826-1844, Petrefacta Germaniae, tam ea, Quae in Museo Universitatis Regiae Borussicae Fridericiae Wilhelmiae Rhenanea, serventur, quam alia quaecunque in Museis Hoeninghusiano Muensteriano aliisque, extant, iconibus et descriiptionns illustrata. - Abbildungen und Beschreibungen der Petrefacten Deutschlands und der Angränzende Länder, unter Mitwirkung des Hern Grafen Georg zu Münster, herausgegeben von August Goldfuss. v. 1 (1826-1833), Divisio prima. Zoophytorum reliquiae, p. 1-114; Divisio secunda. Radiariorum reliquiae, p. 115-221 [Echinodermata]; Divisio tertia. Annulatorium reliquiae, p. 222-242; v. 2 (1834-1840), Divisio quarta. Molluscorum acephalicorum reliquiae. I. Bivalvia, p. 65-286; II. Brachiopoda, p. 287-303; III. (18411844), Divisio quinta. Molluscorum gasteropodum reliquiae, p. 1-121; atlas of plates, 1-199, Düsseldorf, Arnz \& Co.

Gorzelak, P., Salamon, M.A., Trzęsiok, D., Lach, R., and Baumiller, T.K., 2015, Diversity dynamics of post-Palaeozoic crinoids-In quest of the factors affecting crinoid macroevolution: Lethaia, v. 49, p. 231-244.

Gould, S.J., Gilinsky, N.L, and German, R.Z., 1987, Asymmetry of lineages and the direction of evolutionary time: Science, v. 236, p. 1437-1441.

Guensburg, T.E., 2010, Alphacrinus new genus and origin of the disparid clade: Journal of Paleontology, v. 84, p. 1209-1216.

Guensburg, T.E., 2012, Phylogenetic implications of the oldest crinoids: Journal of Paleontology, v. 86, p. 455-461.

Guensburg, T.E., and Sprinkle, J., 2003, The oldest known crinoids (Early Ordovician, Utah) and a new crinoid plate homology system: Bulletins of American Paleontology, v. 364, 43 p.

Guensburg, T.E., and Sprinkle, J., 2007, Phylogenetic implications of the Protocrinoida: Blastozoans are not ancestral to crinoids: Annals de Paleontologie, v. 93, p. 277-290.

Guensburg, T.E., and Sprinkle, J., 2009, Solving the mystery of crinoid ancestry: New fossil evidence of arm origin and development: Journal of Paleontology, v. 83, p. 350-364. 
Guensburg, T.E., Blake, D.B., Sprinkle, J., and Mooi, R., 2016, Crinoid ancestry without blastozoans: Acta Palaeontological Polonica, v. 61, p. 253-266.

Gyllenhaal, J.A., 1772, Beskrifning på de så kallade Crystall-äplen och kalkbollar, såsom petreficerade Djur af Echini genus, eller dess närmaste slägtingar: Kongl. Svenska Vetenskaps Academiens Handlingar, v. 33, p. 239-261.

Hall, J., 1847, Palaeontology of New York Volume I. Containing Descriptions of the Organic Remains of the Lower Division of the New-York System (Equivalent of the Lower Silurian Rocks of Europe). Natural History of New York, Part 6: New York, C. Van Benthuysen, Albany, 338 p.

Hall, J., 1852, Palaeontology of New York Volume II. Containing Descriptions of the Organic Remains of the Lower Middle Division of the New-York System. Natural History of New York, Part 6: New York, D. Appleton \& Co. and Wiley \& Putnam; Boston, Gould, Kendall, \& Lincoln, 362 p.

Hall, J., 1858, Chapter 8. Palaeontology of Iowa, in Hall, J. and Whitney, J.D. Report of the Geological Survey of the state of Iowa. Embracing the results of investigations made during portions of the years $1855,56 \& 57$, v. 1 , part II; Palaeontology, p. 473-724.

Hall, J., 1859, Contributions to the palaeontology of Iowa, being descriptions of new species of Crinoidea and other fossils: Geological Report of Iowa, Supplement to volume I, part II, p. 1-92.

Hall, J., 1866, Descriptions of new species of Crinoidea and other fossils from the lower Silurian strata of the age of the Hudson-River Group and Trenton Limestone: Albany, privately distributed reprint, $17 \mathrm{p}$.

Hays, B., Rouse, G., Thomas, J., and Messing, C., 2015, Can morphology support new molecular phylogenies of Antedonidae (Crinoidea: Comatulida)?: 15th International Echinoderm Conference Abstracts, p. 41-42.

Hemery, L.G., Roux, M., Ameziane, N., and Eleaume, M., 2013, High-resolution crinoid phyletic inter-relationships derived from molecular data: Cahiers De Biologie Marine, v. 54, p. 511-523.

Hess, H., and Messing, C.G., 2011, Treatise on Invertebrate Paleontology Part T, Echinodermata 2, Revised, Crinoidea 3: Lawrence, University of Kansas and Paleontological Institute, $216 \mathrm{p}$.

Hess, H., Ausich, W.I., Brett, C.E., and Simms, M.J., 1999, Fossil Crinoids: Cambridge, Cambridge University Press, 275 p.

Holtz, T.R., 1996, Phylogenetic taxonomy of the Coelurosauria (Dinosauria: Theropoda): Journal of Paleontology, v. 70, p. 536-538.

Holtz, T.R., 1998, A new phylogeny of the carnivorous dinosaurs: Gaia, v. 15, p. 5-61.

Jablonski, D, and Finarelli, J.A., 2009, Congruence of morphologically-defined genera with molecular phylogenies: Proceedings of the National Academy of Sciences, v. 106, p. 8262-8266.

Jaekel, O., 1894, Über die Morphogenie und Phylogenic der Crinoiden: Sitzungsberichten der Gesellschaft Naturforschender Freunde, Jahrgang 1894 , v. 4, p. 101-121

Jaekel, O., 1918, Phylogenie und System der Pelmatozoen: Paläeontologische Zeitschrift, v. 3, p. 1-128.

Kammer, T.W., and Ausich, W.I., 1992, Advanced cladid crinoids from the Middle Mississippian of the east-central United States: Primitive-grade calyces: Journal of Paleontology, v. 66, p. 461-480.

Kammer, T.W., and Ausich, W.I., 1996, Primitive cladid crinoids from upper Osagean-lower Meramecian (Mississippian) rocks of east-central United States: Journal of Paleontology, v. 70, p. 835-866.

Kammer, T.W., and Gahn, F.J., 2003, Primitive cladid crinoids from the early Osagean Burlington Limestone and the phylogenetics of Mississippian species of Cyathocrinites: Journal of Paleontology, v. 77, p. 121-138.

Kammer, T.W., Sumrall, C.D., Zamora, S., Ausich, W.I., and Deline, B., 2013 Oral region homologies in Paleozoic crinoids and other plesiomorphic pentaradiate echinoderms: PLoS ONE, v. 8.11, e77989.

Kelley, P.H., Fastovsky, D.E., Wilson, M.A., Laws, R.A., and Raymond, A., 2013, From paleontology to paleobiology: A half-century of progress in understanding life history: Geological Society of America Special Paper, v. 500 , p. $191-232$.

Kelly, S.M., 1982, Origin of the crinoid orders Disparida and Cladida: Possible inadunate cup plate homologies: Third North American Paleontological Convention (Montreal), Proceedings Abstracts, Montreal, Canada, p. 285-290

Kelly, S.M., 1986, Classification and evolution of class Crinoidea: Fourth North American Paleontological Convention, Abstracts, p. A23.

Kesling, R.V., and Paul, C.R.C., 1968, New species of Porocrinidae and brief remarks upon these unusual crinoids: University of Michigan Contributions from Museum of Paleontology, v. 22, p. 1-32.

Kirk, E., 1914, Notes on the fossil crinoid genus Homocrinus Hall: United States National Museum Proceedings, v. 46, p. 473-483.

Kitazawa, K., Oji, T., and Sunamura, M., 2007, Food composition of crinoids (Crinoidea: Echinodermata) in relation to stalk length and fan density: Their paleoecological implications: Marine Biology, v. 152, p. 959-968.

Kolata, D.R., 1982, Camerates, in Sprinkle, J., ed. Echinoderm faunas from the Bromide Formation (Middle Ordovician) of Oklahoma: The University of Kansas Paleontological Contributions, Monograph, v. 1, p. 170-205.
Lahaye, M.C., and Jangoux, M., 1987, The skeleton of the stalked stages of the comatulid crinoid Antedon bifida (Echinodermata): Zoomorphology, v. 107 , p. $58-65$.

Lane, N.G., 1978, Historical review of classification of Crinoidea, in Moore, R.C., and Teichert, C., eds., Treatise on Invertebrate Paleontology, Part T, Echinodermata 2, v. 2: Lawrence, Kansas, Geological Society of America and University of Kansas Press, p. T348-T358.

Lee, M.S., and Palci, A., 2015, Morphological phylogenetics in the genomic age: Current Biology, v. 25, p. R922-R929.

Le Menn, J., and Spjeldnaes, N., 1996, Un nouveau crinoïde Dimerocrinitidae (Camerata, Diplobathrida) de l'Ordovicien supérieur du Maroc: Rosfacrinus robustus nov. gen., nov. sp: Geobios, v. 29, p. 341-351.

Leuckart, R. von, 1848, Uber de Morphologie und die Verandtschaftsverhältnisse der wibellosen Thiere: Braunschweig, Friedrich, Vieweg \& Sohn, $180 \mathrm{p}$

Matsumoto, H., 1929, Outline of a classification of Echinodermata: Science Reports of the Tohoku Imperial University, Sendai, Japan, Second Series (Geology), v. 8, p. 27-33.

McIntosh, G.C., 1984, Devonian cladid inadunate crinoids: Family Botryocrinidae Bather, 1899: Journal of Paleontology, v. 58, p. 1260-1281.

McIntosh, G.C., 1986, Phylogeny of the dicyclic inadunate crinoid order Cladida: Fourth North American Paleontological Convention Abstracts, p. A31.

McIntosh, G.C., 2001, Devonian cladid crinoids: Families Glossocrinidae Goldring, 1923, and Rutkowskicrinidae new family: Journal of Paleontology, v. 75, p. 783-807.

Meek, F.B., 1873, Descriptions of invertebrate fossils of the Silurian and Devonian systems: Ohio Geological Survey, v. 1, pt. 2 p. 1-243.

Meek, F., and Worthen, A.H., 1869, Descriptions of new Crinoidea and Echinoidea, from the carboniferous rocks of the western states, with a note on the Genns Onychaster: Proceedings of the Academy of Natural Sciences of Philadelphia, v. 21, p. 67-83

Messing, C.G., and White, C.M., 2001, A revision of the Zenometridae (new rank) (Echinodermata, Crinoidea, Comatulidina): Zoologica Scripta, v. 30, p. 159-180.

Meyer, D.L., and Macurda, D.B., 1977, Adaptive radiation of the comatulid crinoids: Paleobiology, v. 3, p. 74-82.

Miller, J.S., 1821, A Natural History of the Crinoidea, or Lily-Shaped Animals with Observations on the Genera, Asteria, Euryale, Comatula and Marsupites: Bristol, C. Frost, $150 \mathrm{p}$.

Miller, S.A., 1883, The American Palaeozoic fossils: A catalogue of the genera and species, with names of authors, dates, places of publication, groups of books in which found, and the etymology and significance of the words, and an introduction devoted to the stratigraphical geology of the Palaeozoic rocks (second edition), Echinodermata: Cincinnati, Ohio, p. 247-334.

Miller, S.A., and Gurley, W.F.E., 1894, New genera and species of Echinodermata: Illinois State Museum of Natural History, v. 5, 53 p.

Miquel, J., 1894, Note sur la géologie des terrains primaires du département de l'Hérault. Le Cambrien et l'Arenig: Bulletin de la Société d'étude des Sciences naturelles de Béziers, v. 17, p. 5-36.

Mooi, R., and David, B., 1998, Evolution within a bizarre phylum: Homologies of the first echinoderms: American Zoologist, v. 38, p. 965-974.

Mooi, R., and David, B., 2008, Radial symmetry, the anterior/posterior axis, and echinoderm Hox genes: Annual Review of Ecology, Evolution, and Systematics, v. 39, p. 43-62.

Moore, R.C., 1962, Ray structures of some inadunate crinoids: University of Kansas Paleontological Contributions, v. 5, p. 1-47.

Moore, R.C., and Laudon, L.R., 1943, Evolution and classification of Paleozoic crinoids: Geological Society of America Special Paper, no. 46151 p.

Moore, R.C., and Teichert, C., eds., 1978, Treatise on Invertebrate Paleontology, Part T, Echinodermata 2: Lawrence, Kansas, Geological Society of America and University of Kansas Press, $1027 \mathrm{p}$.

Moore, R.C., Lalicker, C.G., and Fischer, A.G., 1952, Invertebrate Fossils: New York, McGraw-Hill Book Company, 766 p.

Moore, R.C., Lane, N.G., and Strimple, H.L., 1978a, Order Cladida Moore and Laudon, 1943, in Moore, R.C., and Teichert, C., eds., Treatise on Invertebrate Paleontology, Part T, Echinodermata 2: Lawrence, Kansas, Geological Society of America and University of Kansas Press, p. T578-T759.

Moore, R.C., Lane, N.G., Strimple, H.L., and Sprinkle, J., 1978b, Systemetic descriptions, Crinoidea, Order Disparida, in Moore, R.C., and Teichert, C., eds., Treatise on Invertebrate Paleontology, Part T, Echinodermata 2: Lawrence, Kansas, Geological Society of America and University of Kansas Press, p. T520-T564.

Müller, J., 1841, Uber die Gattungen und Arten der Comatulen: Archiv für Naturgeschichte, v. 7, p. 179-189.

O'Malley, C.E., Ausich, W.I., and Chin, Y., 2016, Deep echinoderm phylogeny preserved in organic molecules from Paleozoic fossils: Geology, v. 44, p. 379-382.

Padian, K., Hutchinson, J.R., and Holtz, T.R., 1999, Phylogenetic definitions and nomenclature of the major taxonomic categories of the carnivorous 
Dinosauria (Theropoda): Journal of Vertebrate Paleontology, v. 19, p. 69-80.

Parks, W.A., 1908, On an occurrence of Hybocystites in Ontario: Ottawa Naturalist, v. 21 , p. 232-236.

Paul, C.R.C., 1968, Macrocystella Callaway, the earliest glyptocystitid cystoid: Palaeontology, v. 11, p. 580-600.

Paul, C.R.C., 1972, Cheirocystella antiqua gen. et sp. nov. from the Lower Ordovician of western Utah and its bearing on the evolution of the Cheirocrinidae (Rhombifera: Glyptocystitida): Brigham Young University Geology Studies, v. 19, p. 15-63.

Paul, C.R.C., 1988, The phylogeny of the cystoids, in Paul, C.R.C., and Smith, A.B., eds, Echinoderm phylogeny and evolutionary biology: Oxford, Clarendon Press, p. 199-213.

Paul, C.R.C., and Smith, A.B., 1984, The early radiation and phylogeny of echinoderms: Biological Reviews, v. 59, p. 443-481.

Pennant, T., 1777, The British Zoology, Volume 4 (fourth edition): London, Warrington.

Peters, S.E., and Ausich, W.I., 2008, A sampling-adjusted macroevolutionary history for Ordovician-early Silurian crinoids: Paleobiology, v. 34, p. 104-116.

Phillips, J., 1836, Illustrations of the Geology of Yorkshire, or a Description of the Strata and Organic Remains, Part 2, The Mountain Limestone districts (second edition): London, John Murray, p. 203-208.

Phillips, J., 1841, Figures and Descriptions of the Palaeozoic Fossils of Cornwall, Devon, and West Somerset; Observed in the Course of the Ordinance Geological Survey of that District: London, Longmans, Brown, Green, and Longmans, 232 p.

Pisani, D., Feuda, R., Peterson, K.J., and Smith, A.B., 2012, Resolving phylogenetic signal from noise when divergence is rapid: A new look at the old problem of echinoderm class relationships: Molecular Phylogenetics and Evolution, v. 62, p. 27-34.

Potter, D., and Freudenstein, J.V., 2005, Character-based phylogenetic Linnaean classification: Taxa should be both ranked and monophyletic: Taxon, v. 54, p. $1033-1035$.

Pyron, R.A., 2015, Post-molecular systematics and the future of phylogenetics: Trends in Ecology and Evolution, v. 30, p. 389-394.

Rasmussen, H.W., 1978, Articulata, in Moore, R.C., and Teichert, K., eds., Treatise on Invertebrate Paleontology, Part T, Echinodermata 2, Volume 2: Boulder and Lawrence, The Geological Society of America and University of Kansas Press, p. T813-T997.

Reich, A., Dunn, C., Akasaka, K., and Wessel, G., 2015, Phylogenomic analyses of Echinodermata support the sister groups of Asterozoa and Echinozoa: PLoS ONE, v. 10, p. e0119627.

Rouse, G.W., Jermiin, L.S., Wilson, N.G., Eeckhaut, I., Lanterbecq, D., Oji, T., Young, C.M., Browning, T., Cisternas, P., Helgen, L.E., Stuckey, M., and Messing, C.G., 2013, Fixed, free, and fixed: The fickle phylogeny of extant Crinoidea (Echinodermata) and their Permian-Triassic origin: Molecular Phylogenetics and Evolution, v. 66, p. 161-181.

Rouse, G.W, Carvajal, J., Oji, T., and Messing, C.G., 2015, Further insights into extant crinoid phylogeny from molecular sequence data: 15 th International Echinoderm Conference Abstracts, p. 67-68.

Roux, M., 1987, Evolutionary ecology and biogeography of recent stalked crinoids as a model for the fossil record, in Jangoux, M., and Lawrence, J.M., eds., Echinoderm Studies, Volume 2: Rotterdam, A.A. Balkma, p. 1-53.

Roux, M., Eleaume, M., Hemery, L.G., and Ameziane, N., 2013, When morphology meets molecular data in crinoid phylogeny: A challenge: Cahiers de Biologie Marine, v. 54, p. 541-548.

Ruta, M., Coates, M.I., and Quicke, D.L.J., 2003, Early tetrapod relationships revisited: Biological Reviews, v. 78, p. 251-345.

Schuchert, C., 1900, On the lower Silurian (Trenton) fauna of Baffin Land: Proceedings of the U.S. National Museum, v. 22, p. 143-178.

Sereno, P.C., 1997, The origin and evolution of dinosaurs: Annual Review of Earth and Planetary Sciences, v. 25, p. 235-489.

Sereno, P.C., 1999, Definitions in phylogenetic taxonomy: Critique and rationale: Systematic Biology, v. 48, p. 329-351.

Sereno, P.C., 2005, The logical basis of phylogenetic taxonomy: Systematic Biology, v. 54, p. 595-619.

Sereno, P.C., McAllister, S., and Brusatte, S.L., 2005, TaxonSearch: A relational database for suprageneric taxa and phylogenetic definitions: PhyloInformatics, v. 8, p. 1-21.

Sevastopulo, G.D., and Lane, N.G., 1988, Ontogeny and phylogeny of disparid crinoids, in Paul, C.R.C., and Smith, A.B., eds., Echinoderm Phylogeny and Evolutionary Biology: Oxford, Clarendon Press, p. 245-253.

Shibata, T.F., Sato, A., Oji, T., and Akasaka, K., 2008, Development and growth of the feather star Oxycomantus japonicus to sexual maturity: Zoological Science, v. 25, p. 1075-1083.

Sibley, C.G., 1994, On the phylogeny and classification of living birds: Journal of Avian Biology, v. 25, p. 87-92.

Sieverts-Doreck, H., 1953, Sous-classe 4, Articulata, in Priveteau, J., ed., Traité de paléontologie, Volume 3: Paris, Masson and Cie, p. 756-765.
Simms, M.J., 1988, The phylogeny of post-Palaeozoic crinoids, in Burke, R.D., Mladenov, P.V., Lambert, P., and Parsley, R.L., eds., Echinoderm Biology: Rotterdam, Balkema, p. 97-102.

Simms, M.J., and Sevastopulo, G.D., 1993, The origin of articulate crinoids: Palaeontology, v. 36, p. 91-109.

Simpson, G.G., 1944, Tempo and Mode in Evolution: New York, Columbia University Press, $237 \mathrm{p}$

Smith, A.B., 1984, Classification of the Echinodermata: Palaeontology, v. 27, p. $431-459$.

Smith, A.B., 1985, Cambrian eleutherozoan echinoderms and the early diversification of edrioasteroids: Palaeontology, v. 28, p. 87-89.

Smith, A.B., 1988, Patterns of diversification and extinction in early Palaeozoic echinoderms: Palaeontology, v. 31, p. 799-828.

Smith, A.B., 1990, Evolutionary diversification of the echinoderms during the early Paleozoic: Systematics Association, Special Volume 42, p. 256-286.

Smith, A.B., 1994, Systematics and the Fossil Record: Documenting Evolutionary Patterns: Oxford, Blackwell Science, $223 \mathrm{p}$

Smith, A.B., 2005, The pre-radial history of echinoderms: Geological Journal, v. 40 , p. $255-280$

Smith, A.B., 2008, Duterostomes in a twist: The origins of a radical new body plan: Evolution and Development, v. 10, p. 493-503.

Smith, A.B., and Jell, P.A., 1990, Cambrian edrioasteroids from Australia and the origin of starfishes: Queensland Museum Memoir, v. 28, p. 715-778.

Smith, A.B., and Zamora, S., 2013, Cambrian spiral-plated echinoderms from Gondwana reveal the earliest pentaradial body plan: Proceedings of the Royal Society B, v. 280, 20131197, doi.org/ 10.1098/rspb.2013.1197.

Soul, L.C., and Friedman, M., 2015, Taxonomy and phylogeny can yield comparable results in comparative paleontological analyses: Systematic Biology, v. 64, p. 608-620.

Springer, F., 1911, On a Trenton echinoderm fauna: Canada Department Mines Memoir no. 15-P, $70 \mathrm{p}$

Springer, F., 1913, Crinoidea, in Zittel, K.A. von, ed., Text-book of Paleontology, Volume 1, (translated and edited by C.R. Eastman (second edition): London, Macmillan \& Co., Ltd, p. 173-243.

Springer, F., 1920, The Crinoidea Flexibilia: Smithsonian Institution Publication no $2501,486 \mathrm{p}$

Sprinkle, J., 1973, Morphology and evolution of blastozoan echinoderms: Museum of Comparative Zoology Special Publication, Harvard University, $283 \mathrm{p}$.

Sprinkle, J., 1976, Classification and phylogeny of "pelmatozoan" echinoderms: Systematic Zoology, v. 25, p. 83-91

Sprinkle, J., 1982a, Cylindrical and globular rhombiferans, in Sprinkle, J., ed., Echinoderm faunas from the Bromide Formation (Middle Ordovician) of Oklahoma: The University of Kansas Paleontological Contributions, Monograph, v. 1, p. 231-273.

Sprinkle, J., 1982b, Hybocrinus, in Sprinkle, J., ed., Echinoderm faunas from the Bromide Formation (Middle Ordovician) of Oklahoma: The University of Kansas Paleontological Contributions, Monograph 1, p. 119-128.Sprinkle, J., and Moore, R.C., 1978, Hybocrinida, in Moore, R.C. and Teichert, C., eds., Treatise on Invertebrate Paleontology, Part T, Echinodermata 2: Lawrence, Kansas, Geological Society of America and University of Kansas Press, p. T564-T574.

Stukalina, G.A., 1980, New species of quadrilaterial from the Ordovician of Kazakhstan, Urals, and eastern European platform, in Stukalina, G.A., ed., New species of ancient plants and invertebrates of the USSR, 5: Moscow, Akademiia Natik SSSR, Paleontologischeskii Institut, p. 88-95.

Summers, M.M., Messing, C.G., and Rouse, G.W., 2014, Phylogeny of Comatulidae (Echinodermata: Crinoidea: Comatulida): A new classification and an assessment of morphological characters for crinoid taxonomy: Molecular Phylogenetics and Evolution, v. 80, p. 319-339.

Sumrall, C.D., 1997, The role of fossils in phylogenetic reconstructions of the Echinodermata: Paleontological Society Papers, v. 3, p. 267-288.

Sumrall, C.D., 2008, The origin of Lovéns Law in glyptocystitoid rhombiferans and its bearing on plate homology and heterochronic evolution of the hemicosmitoid peristomial border, in Ausich, W.I., and Webster, G.D., eds., Echinoderm Paleobiology: Bloomington, Indiana University Press, p. 28-41.

Sumrall, C.D., 2010, A model for elemental homology for the peristome and ambulacra in blastozoan echinoderms, in Harris, L.G., Bottger, S.A., Walker, C.W., and Lesser, M.P., eds., Echinoderms: Durham: New York, CRC Press, p. 269-276.

Sumrall, C.D., 2014, Echinoderm phylogeny-The path forward: Geological Society of America Abstracts with Programs, v. 46, p. 78.

Sumrall, C.D., and Waters, J.A., 2012, Universal elemental homology in glyptocystitoids, hemicosmitoids, coronoids, and blastoids: Steps toward echinoderm phylogenetic reconstruction in derived blastozoans: Journal of Paleontology, v. 68, p. 956-972.

Sumrall, C.D., and Wray, G.A., 2007, Ontogeny in the fossil record: Diversification of body plans and the evolution of "abberant" symmetry in Paleozoic echinoderms: Paleobiology, v. 33, p. 149-163. 
Telford, M.J., Low, C.J., Cameron, C.B., Ortega-Martinez, O., Aronowicz, J. Oliveri, P., and Copley, R.R., 2014, Phylogenetic analysis of echinoderm class relationships supports Asterozoa: Proceedings of the Royal Society B, v. 281, 20140479.

Ubaghs, G., 1963, Rhopalocystis destombesi n. g., n. sp. Eocrinoide de l'Ordovicien inferieur (Tremadocien superieur) du Sud marocain: Notes du service geologic du Maroc, v. 23, p. 25-44.

Ubaghs, G., 1978, Origin of crinoids, in Moore, R.C., and Teichert, C., eds., Treatise on Invertebrate Paleontology, Part T, Echinodermata, Volume 2, 2 Lawrence, Kansas, Geological Society of America and University of Kansas Press, p. T275-T281.

Ulrich, E.O., 1925, The lead, zinc, and fluorspar deposits of Western Kentucky; Chapter 2, Stratigraphic geology: U. S. Geological Survey, Professional Paper 36, p. 22-71.

Wachsmuth, C., and Springer, F., 1880-1886, Revision of the Palaeocrinoidea. Proceedings of the Academy of Natural Sciences of Philadelphia Part I. The families Ichthyocrinidae and Cyathocrinidae (1880), p. 226-378 (separate repaged p. 1-153). Part II. Family Sphaeroidocrinidae, with the sub-families Platycrinidae, Rhodocrinidae, and Actinocrinidae (1881), p. 177-411 (separate repaged, p. 1-237). Part III, Sec. 1. Discussion of the classification and relations of the brachiate crinoids, and conclusion of the generic descriptions (1885), p. 225-364 (separate repaged, 1-138). Part III, Sec. 2. Discussion of the classification and relations of the brachiate crinoids, and conclusion of the generic descriptions (1886), p. 64-226 (separate repaged to continue with section 1, 139-302).

Wachsmuth, C., and Springer, F., 1891, The perisomic plates of the crinoids: Proceedings of the Academy of Natural Sciences of Philadelphia, v. 41, p. $345-39$.

Wachsmuth, C., and Springer, F., 1897, The North American Crinoidea Camerata: Harvard College Museum of Comparative Zoology Memoir, v. 20 and 21,897 p.

Webster, G.D., and Jell, P.A., 1999, New Permian crinoids from Australia: Memoirs of the Queensland Museum, v. 33, p. 349-359.

Webster, G.D., and Lane, N.G., 2007, New Permian crinoids from the Battleship Wash patch reef in southern Nevada: Journal of Paleontology, v. 81, p. 951-965.

Wetherby, A.G., 1880, Remarks on the Trenton Limestone of Kentucky, with descriptions of new fossils from that formation and the Kaskaskia (Chester) Group, Sub-carboniferous: Journal of the Cincinnati Society of Natural History, v. 3, p. 144-160.
White, C.A., 1881, Fossils of the Indiana rocks: Indiana Department of Statistics and Geology, Annual Report, v. 2, p. 471-522.

Wiley, E.O., and Lieberman, B.S., 2011, Phylogenetics: Theory and Practice of Phylogenetic Systematics: Hoboken, NJ, John Wiley \& Sons, 406 p.

Wright, D.F., 2015a, Fossils, homology, and "Phylogenetic Paleo-ontogeny": A reassessment of primary posterior plate homologies among fossil and living crinoids with insight from developmental biology: Paleobiology, v. 41 , p. $570-591$.

Wright, D.F., 2015b, Testing the taxonomic structure of Paleozoic pan-cladid crinoids: A statistical approach using the fossilized birth-death process and Bayesian phylogenetic inference: Geological Society of America Abstracts with Programs, v. 7, p. 854.

Wright, D.F., 2017, Bayesian estimation of fossil phylogenies and the evolution of early to middle Paleozoic crinoids (Echinodermata): Journal of Paleontology, doi: 10.1017/jpa.2016.141.

Wright, D.F., and Ausich, W.I., 2015, From the stem to the crown: Phylogeny and diversification of pan-cladid crinoids, in Zamora, S., and Rábano, I., eds., Progress in Echinoderm Paleobiology: Cuadernos del museo Geominero, v. 19 Instituto Geológico y Minero de España, p. 199-202.

Zamora, S., 2013, Morphology and phylogenetic interpretation of a new Cambrian edrioasteroid (Echinodermata) from Spain: Palaeontology, v. 56, p. $421-431$.

Zamora, S., and Rahman, I.A., 2014, Deciphering the early evolution of echinoderms with Cambrian fossils: Palaeontology, v. 57, p. 1105-1119.

Zamora, S., and Smith, A.B., 2011, Cambrian stalked echinoderms show unexpected plasticity of arm construction: Proceedings of the Royal Society of London B: Biological Sciences, rspb20110777.

Zamora, S., Sumrall, C.D., and Vizcaino, D., 2013, Morphology and ontogeny of the Cambrian edrioasteroid echinoderm Cambraster cannati from western Gondwana: Acta Palaeontologica Polonica, v. 58, p. 545-559.

Zamora, S., Sumrall, C.D., Zhu, X., and Lefebvre, B., 2016, A new stemmed echinoderm from the Furongian of China and the origin of Glyptocystitida (Blastozoa, Echinodermata): Geological Magazine, doi: 10.1017/S001675 $681600011 \mathrm{X}$

Zittel, K.A. von, 1895, Grundzüge der Palaeontologie (Palaeozoologie) (first edition) München, R. Oldenbourg, 971 p.

Accepted 2 September 2016 